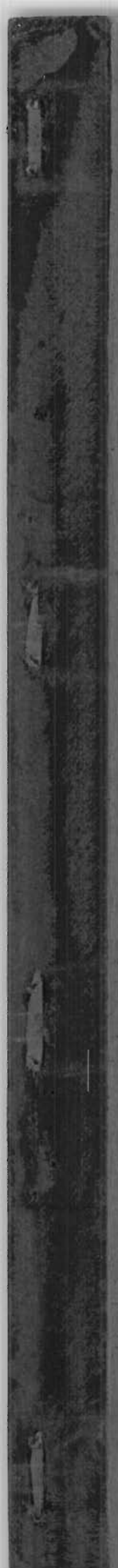

\title{
HEAT TRANSFER FROM SOLIDIFIED WASTES IN UNDERGROUND STORAGE TANKS
}

W. E. WILLINGHAM and G. JANSEN, JR.

OCTOBER, 1966

\section{BAtTELLE=NORTHWEST}

BATTELLE MEMORIAL INSTITUTE / PACIFIC NORTHWEST LABORATORY 


\section{LEGAL NOTICE}

This report was prepared as an account of Government sponsored work. Neither the United States, nor the Commission, nor any person acting on behalf of the Commission:

A. Makes any warranty or representation, expressed or implied, with respect to the accuracy, completeness, or usefulness of the information contained in this report, or that the use of any informotion, apparatus, method, or process disclosed in this report may not infringe privately owned rights; or

B. Assumes any liabilities with respect to the use of, or for damages resulting from the use of any information, apparatus, method, or process disclosed in this report.

As used in the above, "person acting on behalf of the Commission" includes any employee or contractor of the Commission, or employee of such contractor, to the extent that such employee or contractor of the Commission, or employee of such contractor prepares, disseminates, or provides access to, any information pursuant to his employment or contract with the Commission, or his employment with such contractor.

\section{PACIFIC NORTHWEST LABORATORY}

RICHLAND, WASHINGTON

operated by

BATTELLE MEMORIAL INSTITUTE

for the

UNITED STATES ATOMIC ENERGY COMMISSION UNDER CONTRACT AT(45-1)-1830 


$$
\begin{gathered}
M 40 \\
\text { BNWL-262 } \\
\text { UC-70, Waste Disposal } \\
\text { and Processing }
\end{gathered}
$$

\title{
HEAT TRANSFER FROM SOLIDIFIED WASTES \\ IN UNDERGROUND STORAGE TANKS
}

By

\author{
W. E. Willingham and G. Jansen, Jr. \\ Chemical Development Section \\ Chemistry Department
}

\author{
October, 1966
}

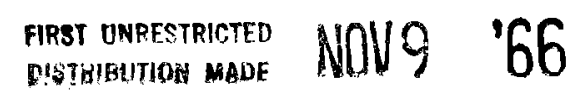

PACIFIC NORTHWEST LABORATORY

RICHLAND, WASHINGTON 
Printed in USA. Price \$3.00. Available from the Clearinghouse for Federal Scientific and Technical Information National Bureau of Standards

U.S. Department of Commerce Springfield, Virginia 22151 


\title{
HEAT TRANSFER FROM SOLIDIFIED WASTES IN UNDERGROUND STORAGE TANKS
}

\begin{abstract}
Steady state temperature distributions in and around buried radioactive waste storage tanks have been calculated for solidified cakes containing heat-generating fission products. The most important factors influencing the maximum cake and wall temperatures were the quantity of heat generated, the soil thermal conductivity, and the soil cover depth with the heat transfer conditions inside the tank of secondary importance.
\end{abstract}


$\bullet$

.

$:$

1

.

.

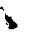

.

. 


\section{CONTENTS}

LIST OF FIGURES

NOMENCLATURE

INTRODUCTION

SUMMARY

HANFORD WASTE STORAGE TANKS

Computer Program for Iterative Calculations 。 . . 5

Temperature Distribution in the System . . . . 7

Effect of Cake Thickness 。 . . . . . . . 8

Effect of Soil Depth • . 。 . . . . . . 8

Effect of Thermal Conductivity 。 . 。 . • 。 13

APPROXIMATE MODEL . 。 . . . . . . 16

Development of the Model . . . . . . . 16

Comparison of the Mode1 with Iterative Results . $\quad 18$

Stratification of Heat-Generating Fission Products 。 18

Temperature Gradients in the Concrete Liner . 。 . 21

Use of the Approximate Mode1 。 . . . 。 . 21

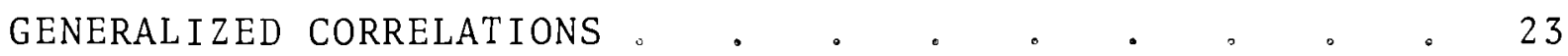

Dimensional Analysis 。 . . . . . . . . 23

Correlation of Major Variables 。 . . . 。 . 26

Effect of Soil Cover Depth . . . . . 27

Effect of Tank Spacing 。 . . 。 . . 27

Effect of Water Table Depth . . . . . 。. 33

Effect of Tank Height。 . 。 . . . . 。 33

ACKNOWLEDGMENT 。. $\circ \circ \circ \circ 6$

APPENDIXES

A RESUltS OF ITERATIVE CALCUlations。 。 . • $\quad 37$

B。 DERIVATION OF EQUATIONS FOR THE APPROXIMATE MODEL • 43

C. UTTA--COMPUTER PROGRAM FOR CALCULATIONS USING

THE APPROXIMATE MODEL。 . . . . . 50

D. EXAMPLE PROBLEMS 。 . . 。 . . . 55 REFERENCES 
3

1

. 


\section{LIST OF FIGURES}

1 Schematic Diagram of an Underground Waste Storage Tank.... . . . . . . . . . . 7

2 Temperatures Around an Underground Waste Storage Tank Containing a Solid Cake . . . . . . 9

3 Temperatures Around an Underground Waste Storage Tank Containing a Solid Cake. . . . . . . . 10

4 Temperature Profile in the Horizontal Plane of Maximum Temperature . . . . . . . . . . . . 11

5 Temperature Profile in the Vertical Plane Along the Axis of the Tank. . . . . . . . . . . 11

6 Maximum Temperature in Buried Storage Tanks, Effect of Volumetric Heat Generation Rate . . . 12

7 Heat Dissipation from Buried Radioactive Waste Storage Tanks (Effect of Cake Thickness)

8 Maximum Temperature in Buried Waste Storage Tanks (Effect of Soil Cover Depth) . . . . . . . 13

9 Maximum Temperature in Buried Waste Storage Tanks Effect of Thermal Conductivity and Heat Generation)

10 Correlation of Maximum Temperature with Thermal Conductivity ................. . 15

11 Approximate Model for Heat Flow in a Waste Tank Containing Solidified Wastes . . . . . . . . 17

12 Comparison of Approximate Model with Iterative Calculations... . . . . . . . . . . . . 19

13 Effect of Stratification of Fission Products on the Maximum Cake Temperature . . . . . . . 20

14 Overall Heat Transfer Coefficients . . . . . . 24

15 Maximum Temperature at the Bottom of a Storage Tank (Effect of Soil Cover Depth.. . . . . 28

16 Maximum Temperature at the Bottom of a Waste Storage Tank (Effect of Tank Spacing) . . . . . 29

17 Vertical Temperature Profile at the Axis of a Waste Tank.............. . . 31 
Figure Title

$\underline{\text { Page }}$

18 Temperature Profile in the Plane of Maximum Temperature (Comparison of a Solitary Tank with One in a Tank Farm . . . . . . . . . . 32

19 Maximum Temperature at the Bottom of a Storage Tank Containing Solidified Wastes (Effect of Water Table Depth). . . . . . . . . . . 34

20 Maximum Temperature at the Bottom of a Waste Storage Tank (Effect of Tank Height) . . . . 35

A-1 Block Diagram of Heat Transfer Program 001 . 38 
NOMENCLATURE

$\mathrm{h}_{1}=$ convection heat transfer coefficient, top of cake-to-vapor, $1.5 \mathrm{Btu} /(\mathrm{hr})\left(\mathrm{ft}{ }^{2}\right)\left({ }^{\circ} \mathrm{F}\right)$

$\mathrm{h}_{2}=$ convection heat transfer coefficient, top of vapor space-to-soil, $1.5 \mathrm{Btu} /(\mathrm{hr})\left(\mathrm{ft}{ }^{2}\right)\left({ }^{\circ} \mathrm{F}\right)$

${ }^{h} \mathrm{Q}_{1}=$ convection heat transfer coefficient, side of vapor space-to-soil, $1.5 \mathrm{Btu} /(\mathrm{hr})\left(\mathrm{ft}{ }^{2}\right)\left({ }^{\circ} \mathrm{F}\right)$

$h_{A}=$ convection heat transfer coefficient, soil-to-air, $0.555 \mathrm{Btu} /(\mathrm{hr})\left(\mathrm{ft} \mathrm{t}^{2}\right)\left({ }^{\circ} \mathrm{F}\right)$

$k_{c}=$ thermal conductivity of the cake, Btu/(hr) $\left(f t^{2}\right)\left({ }^{\circ} \mathrm{F} / \mathrm{ft}\right)$

$\mathrm{k}_{\mathrm{d}} \quad=$ thermal conductivity of the nonheat-generating layer of the cake below the heat-generating layer, $\mathrm{B} t \mathrm{u} /(\mathrm{hr})\left(\mathrm{ft} \mathrm{t}^{2}\right)\left({ }^{\circ} \mathrm{F} / \mathrm{ft}\right)$

$k_{g} \quad=$ thermal conductivity of the heat-generating layer of the cake, Btu/(hr) $\left(f t^{2}\right)\left({ }^{\circ} \mathrm{F} / \mathrm{ft}\right)$

$\mathrm{k}_{\mathrm{m}}=$ thermal conductivity of the concrete tank liner, $0.5 \mathrm{Btu} /(\mathrm{hr})\left(\mathrm{ft} \mathrm{t}^{2}\right)\left({ }^{\circ} \mathrm{F} / \mathrm{ft}\right)$

$\mathrm{k}_{\mathrm{s}}=$ thermal conductivity of the $\left.\operatorname{soil}, \mathrm{Btu} / \mathrm{hr}\right)\left(\mathrm{ft} \mathrm{C}^{2}\right)\left({ }^{\circ} \mathrm{F} / \mathrm{ft}\right)$

$\mathrm{k}_{\mathrm{t}}=$ thermal conductivity of the nonheat-generating layer of the cake above the heat-generating layer, $\mathrm{Btu} /(\mathrm{hr})\left(\mathrm{ft} \mathrm{t}^{2}\right)\left({ }^{\circ} \mathrm{F} / \mathrm{ft}\right)$

$k_{v}=$ thermal conductivity of vapor, $200 \mathrm{Btu} /(\mathrm{hr})\left(\mathrm{ft} \mathrm{C}^{2}\right)\left({ }^{\circ} \mathrm{F} / \mathrm{ft}\right)$

$\ell_{1}=$ soil cover depth, ft

$\ell_{2}=$ height of tank vapor space, ft

$\ell_{2}+\ell_{c}=\operatorname{tank}$ height, ft

$\ell_{3}=$ distance from bottom of tank to water table, ft

$\ell_{c} \quad=$ cake thickness, ft

$l_{\mathrm{d}}=$ thickness of the nonheat-generating layer of the cake below the heat-generating layer, ft

$\ell_{g}=$ thickness of the heat-generating layer of the cake, $f t$ 
Q = total heat generated in the cake, Btu/(hr), subscripts refer to parts of this flux

$\mathrm{r}=$ tank radius, $\mathrm{ft}$

$\mathrm{R}=$ half the center-to-center tank spacing, $\mathrm{ft}$

$\mathrm{S}=$ volumetric heat generation rate, $\mathrm{Btu} /(\mathrm{hr})\left(\mathrm{ft}^{3}\right)$

$\mathrm{T}_{\mathrm{A}} \quad=$ atmospheric temperature, $70^{\circ} \mathrm{F}$

$\mathrm{T}_{\text {MAX }}=$ maximum temperature in the cake, ${ }^{\circ} \mathrm{F}$

$\mathrm{T}_{\mathrm{V}} \quad=$ average temperature of the vapor space, ${ }^{\circ} \mathrm{F}$

$\mathrm{T}_{\mathrm{W}} \quad=$ water table temperature, $70^{\circ} \mathrm{F}$

$\mathrm{T}_{1} \quad=$ maximum temperature at the top of the heat-generating layer of the cake, ${ }^{\circ} \mathrm{F}$

$\mathrm{T}_{2}=$ maximum temperature at the bottom of the heatgenerating 1 ayer of the cake, ${ }^{\circ} \mathrm{F}$

All overall heat transfer coefficients are based on the tank horizontal cross-sectional area.

$\mathrm{U}_{\mathrm{D}} \quad=$ overall heat transfer coefficient, bottom of heat generating layer of the cake-to-the water table, $\mathrm{Btu} /(\mathrm{hr})\left(\mathrm{ft} \mathrm{t}^{2}\right)\left({ }^{\circ} \mathrm{F}\right)$

$\mathrm{U}_{\mathrm{U}} \quad=$ overall heat transfer coefficient, top of heat-generating layer of the cake to the atmosphere

$\mathrm{U}_{\mathrm{Q}_{1}}=$ heat transfer coefficient, side of cake-to-atmosphere

$\mathrm{U}_{\mathrm{Q}_{2}}=$ heat transfer coefficient, side of vapor space-toatmosphere

$\mathrm{U}_{\mathrm{Q}_{3}}=$ heat transfer coefficient, side of cake-to-water table

$\mathrm{U}_{\mathrm{Q}_{U}}=$ heat transfer coefficient, for linear flow from the top of the cake to the atmosphere

$\mathrm{U}_{\mathrm{Q}_{\mathrm{D}}}=$ heat transfer coefficient, for linear flow from the bottom of the cake to the water table

$\mathrm{x}_{\mathrm{N}} \quad=$ position of the null plane and maximum cake temperature, measured from the bottom of the heat-generating layer of the cake, ft 


\section{HEAT TRANSFER FROM SOLIDIFIED WASTES \\ IN UNDERGROUND STORAGE TANKS}

INTRODUCTION

One of the most important problems that arise in the underground storage of waste material containing radioactive fission products is the high temperature produced by poor heat dissipation through the surrounding soil. A thermal analysis of underground tank systems has been undertaken by Battelle-Northwest in support of in-tank waste solidification studies (1) conducted by Isochem Inc., as part of the Isochem Waste Management Program.

Solidification is proposed for bismuth phosphate wastes, coating wastes, and aged Redox and Purex wastes, which are presently stored in the underground tanks and which contain alkaline solutions with high concentrations of sodium salts. New wastes, after removal of most of the long lived, heat generating fission products $\mathrm{Cs}^{137}$ and $\mathrm{Sr}^{90}$, would be stored for an interim period until the short lived fission products decay sufficiently to permit solidification. (2)

Previous studies have been concerned with the transient thermal histories involved in startup of tanks containing boiling solutions (3) and evaluation of the combined thermal stresses and load stresses, which determine the amount of solution that can safely be held by a tank. (4) A heat transfer analogue consisting of electrically conductive paper has been developed, (5) and its application to steady state temperatures in boiling tanks has been discussed. (6) Temperatures in tanks which have lost their liquid cover have been calculated, and heat transfer in leaks from buried tanks has been analyzed. (7)

Primarily, this work provides methods for predicting the temperature distributions to be expected in an underground tank system. This analysis deals only with steady state conditions and with idealized materials having thermal properties independent of 
position and temperature. Because of this the results must be regarded only as a reference system with which to compare analyses of real cases and not as a definitive description of the true thermal characteristics of operational waste tank farms.

Parts of this work have been previously reported in quarterly reports $(8,9,10)$ and at the Richland waste symposium in February 1966. (11)

\section{SUMMARY}

Steady state temperature distributions in and around buried waste storage tanks containing solidified cakes have been related to fission product heat generation rates for use in the Isochem In-Tank Waste Solidification Program. The maximum cake and concrete wall temperatures were calculated as a function of soil and cake thermal conductivities, cake thickness, heat generation rate, and soil cover depth by an iterative computer program. Steady state temperature gradients across the concrete tank wall were estimated for a typical system.

The calculations were made for a $75 \mathrm{ft}$ diam tank in a tank farm with $120 \mathrm{ft}$ center-to-center spacing and with heat losses by convection to the atmosphere and to a water table at a depth of $202 \mathrm{ft}$. For this system, about $85 \%$ of the generated heat flows to the atmosphere and the remainder to the water table. About $53 \%$ of the heat flowing to the atmosphere passes through the soil layer directly above the tank. If the total heat generation rate from fission products is assumed constant, variations in the cake thickness have only a small effect on the temperatures in the system. Because most of the resistance to heat flow is in the soil, the thermal conductivity and the depth of the soil above the 'tank strongly affect the maximum temperatures. The cake thermal conductivity is of secondary importance, and the convective heat transfer coefficients and the tank height have almost no effect on the temperatures. In one example, increasing the tank spacing 
from 120 to $600 \mathrm{ft}$ lowers the maximum cake temperature only slightly, from 408 to $332^{\circ} \mathrm{F}$. Stratification of the heat-generating fission products has little effect on the maximum cake temperature. The calculated temperature gradients in the concrete wall for a maximum cake temperature of $350^{\circ} \mathrm{F}$ are less than $10^{\circ} \mathrm{F}$ per foot of wall thickness.

An approximate model which subdivides the heat flow into five distinct paths was developed. It calculates only the temperatures along the tank axis in contrast to the iterative program, which calculates complete temperature maps throughout the system. The model includes all the independent variables used in the more complex iterative computer program, and the calculated maximum temperatures agree within $5 \%$ for the range of investigation. The model can be used to vary many parameters rapidly and to extrapolate from experimental data to other conditions inside the tank.

Generalized correlations for the effect of tank size, height and spacing, soil cover depth, water table depth, and thermal properties of the system are presented. Six example problems are given to aid in calculating maximum temperatures from given information.

\section{HANFORD WASTE STORAGE TANKS}

The quantity of heat-generating fission products that can be stored in an underground tank is limited by the temperatures achieved in the system. The temperature of the solidified waste should remain below its melting point to prevent volatilization of fission products. To maintain structural integrity, the temperature of the tank wall should not exceed the operating limits of the concrete shell. The thermal gradients in the tank wall should not be so high that thermal stresses cause concrete failure. 
At the present time the melting point of the actual solid waste is not known. Although it is dependent upon the composition within a particular tank, it is not expected to exceed $400^{\circ} \mathrm{F}$. The spalling temperature of the concrete was assumed to be $320^{\circ} \mathrm{F}$, the temperature at which it begins to lose its water of hydration. (12)

Several difficulties arise in attempting to describe heat transfer in an underground tank system containing solidified wastes. Inside the tank the heat-generating fission products are not homogeneously distributed, the thermal properties of the solid are not uniform or known accurately, and the heat generation rate varies with time as the fission products decay. Outside the tank, the soil properties are not uniform because of loose backfill near and above the tank, unpredictable variations in moisture content, and an effective soil thermal conductivity which is a strong function of temperature due to heat transfer by moisture recycle. Since the soil is a good insulator, long periods of time are required to establish thermal equilibrium within the soil.

With the above points in mind, we shall limit the discussion to an idealized treatment of the type of waste storage tank that exists at Hanford. The maximum steady-state temperatures to be expected within the system will be calculated for various conditions.

The system considered is

- A steel tank with a concrete she11

$75 \mathrm{ft}$ diam

36 ft high

E11ipsoidal roof

$11 \mathrm{ft}$ nominal soil cover above the tank closure $120 \mathrm{ft}$ center-to-center spacing. 
The factors considered are

- Thermal conductivity of the soil

- Thermal conductivity of the solid waste

- Heat generation rate

- Film coefficients between the cake and vapor, vapor and tank, and the ground surface and the air

- Thickness of soil cover above the tank

- Thickness of the solidified cake

- Sink temperatures (air and water table)

- Heat transfer only by convection and conduction. COMPUTER PROGRAM FOR ITERATIVE CALCULATIONS

To study successfully all the factors involved, it was necessary to make use of the IBM-7090 and Univac 1107 digital computers available at Hanford.

The program used is a modified version of Program 001 "Equilibrium Temperatures in a Generalized Heat Transfer System" which is 1 isted in the FORTRAN Library. (13)

The system to be studied is divided into a maximum of 600 sections, or nodes, not necessarily uniform in size; and these may be numbered either horizontally or vertically. The area, volume, and location of the centroid of each node is required for the calculation. After assuming an initial temperature distribution throughout the system, the program starts at the lowest number node and proceeds through an iterative type calculation for the total number of nodes specified. The iterative calculation is based on the Gauss-Seidel method and is a step-by-step process. No discussion of the method will be given as it is readily available in various texts. $(14,15,16)$

The program considers the heat generation in a finite cylinder with fixed boundaries and a fixed heat generation rate; the buildup to or decay from this value is not considered. 
After all new temperatures are calculated, a heat balance is made to compare the heat leaving the system with the heat being generated. If this balance does not check within preset limits, the calculation is repeated until either the time 1 imit on the program is exceeded or the heat balance is acceptable.

When the calculation is complete, the results are printed as shown for a typical case in Appendix $A$, in which is also shown a brief flow diagram of the computer program, and a 1 ist of the input data.

The following parameters were used in the calculations:

$\begin{array}{ll}\text { Cake thickness, ft } & 4 \text { to } 24 \\ \text { Soil thickness, ft } & 7,11 \\ \text { Heat generation rate, } & 10,000 \text { to } 50,000 \\ \quad \text { Btu/hr } & 0.071 \text { to } 2.83\end{array}$

Thermal conductivity

of the soil, $\mathrm{Btu} /(\mathrm{hr})\left(\mathrm{ft} \mathrm{t}^{2}\right)\left({ }^{\circ} \mathrm{F} / \mathrm{ft}\right) \quad 0.15$ to 0.65

Effective thermal conductivity of the vapor, $B t u /(h r)\left(f t^{2}\right)\left({ }^{\circ} F / f t\right) \quad 200$

Film coefficients, $\mathrm{Btu} /(\mathrm{hr})\left(\mathrm{ft}{ }^{2}\right)\left({ }^{\circ} \mathrm{F}\right) \quad 0.001$ to 6.0

After several trial cases were processed on the computer, it was found that the film coefficients had very little effect upon the temperature unless they were very sma11; these were held constant at reasonable values throughout the calculations.

Boundary conditions assumed for the system are (1) no radial heat flow beyond a $60 \mathrm{ft}$ radius, which approximates the existence of an infinite array of identical tanks in a tank farm with $120 \mathrm{ft}$ center-to-center spacing; (2) a water table at $202 \mathrm{ft}$ depth which serves as an infinite heat sink at $70^{\circ} \mathrm{F}$; and (3) convection to 
the air at ground level (11 feet above the top of the tank). A schematic diagram of a tank is shown in Figure 1. The concrete shell is assumed to have the same thermal properties as the soil for the iterative calculations.

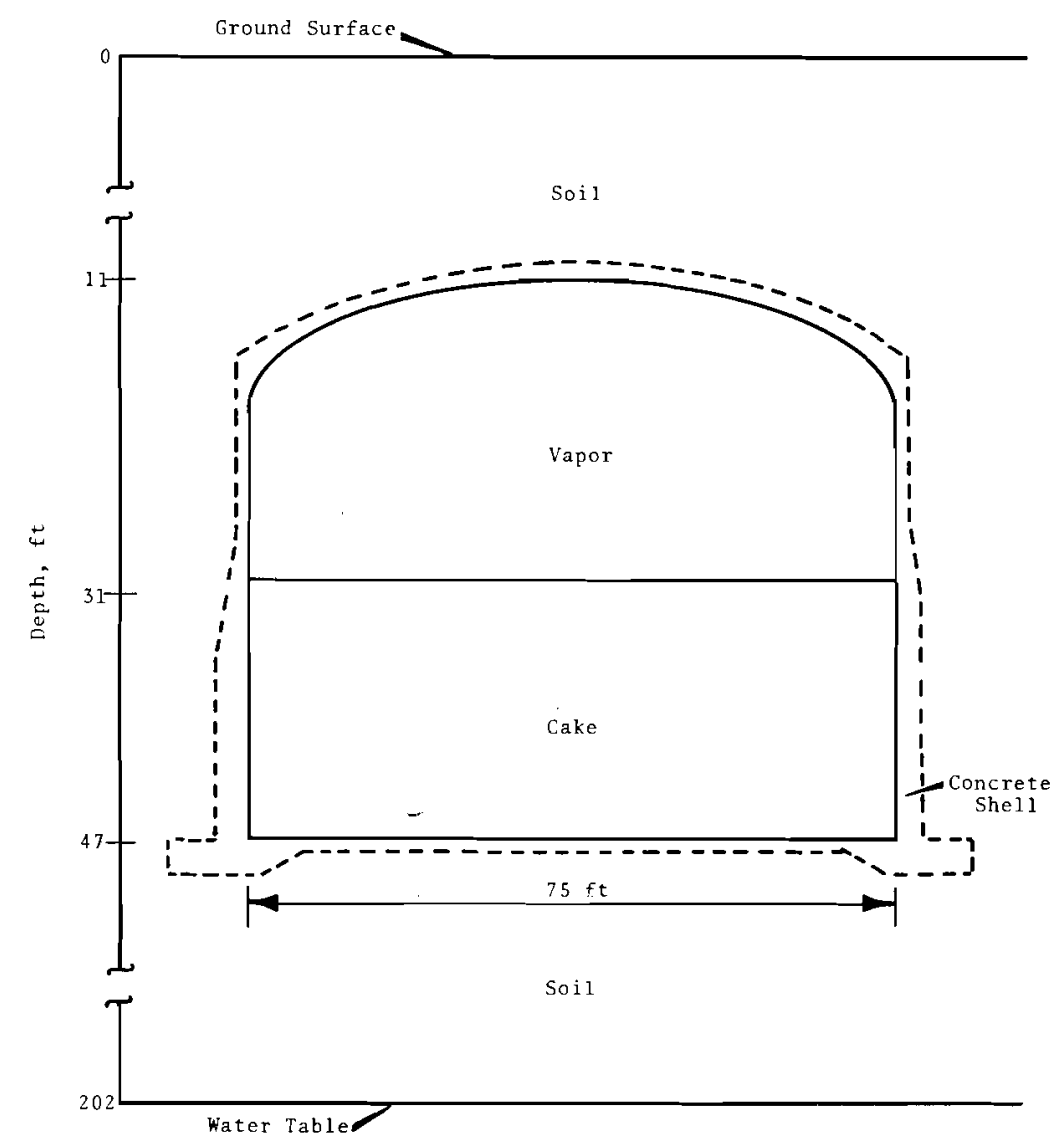

FIGURE 1. Schematic Diagram of an Underground Waste Storage Tank.

TEMPERATURE DISTRIBUTION IN THE SYSTEM

The temperature fields for normal soil [ $\mathrm{k}=0.33 \mathrm{Btu} /(\mathrm{hr})$ $\left.\left(f t^{2}\right)\left({ }^{\circ} \mathrm{F} / \mathrm{ft}\right)\right]$ and for dry soil $\left[\mathrm{k}=0.15 \mathrm{Btu} /(\mathrm{hr})\left(\mathrm{ft} \mathrm{t}^{2}\right)\left({ }^{\circ} \mathrm{F} / \mathrm{ft}\right)\right]$ are shown in Figures 2 and 3 . The maximum temperature in the tank wall, occurring at the center of the bottom of the tank, is $339^{\circ} \mathrm{F}$ and $559^{\circ} \mathrm{F}$ for normal soil and dry soil, respectively. The maximum cake temperature occurs near the bottom of the cake and is $352^{\circ} \mathrm{F}$ and $562^{\circ} \mathrm{F}$, only sightly higher than the wall temperature. Overall energy balances 
show that $84.2 \%$ and $85.4 \%$ of the heat flows through the soil to the atmosphere for Figures 2 and 3 , respectively. Of the heat going to the atmosphere $52.0 \%$ and $52.9 \%$ passes through the soil directly above the tank.

In Figure 4 the temperature profile is presented for a horizontal plane passing through a $16 \mathrm{ft}$ cake at the point of maximum temperature. The cake is generating a total of $35,300 \mathrm{Btu} / \mathrm{hr}$ and reaches a maximum of $\sim 560^{\circ} \mathrm{F}$ at the centerine. At the tank wall (37.5 ft away from the centerline), the temperature is still $500^{\circ} \mathrm{F}$ and is $410^{\circ} \mathrm{F}$ at the $60 \mathrm{ft}$ insulated radius. Figure 5 shows a vertical temperature profile through the same cake as shown in Figure 4, along the centerline of the tank.

\section{EFFECT OF CAKE THICKNESS}

In Figure 6 the maximum cake temperature is shown as a function of the volumetric heat generation rate with cake thickness as a parameter. The temperature increases linearly with volumetric heat generation rate and increases with cake thickness because the total heat generation rate rises. Using $320^{\circ} \mathrm{F}$ at the tank surface as a limit, the quantity of heat-generating material that can be stored drops very rapidly as the cake thickness increases.

Figure 7 contains the same information as in Figure 6 but total heat generation is used as the parameter. The effect of cake thickness on maximum temperature is shown to be small when the total heat generation rate (i.e., the quantity of fission products in the tank) is held constant.

\section{EFFECT OF SOIL DEPTH}

The effect of soil cover depth is shown in Figure 8 . The temperature is decreased only $14.9 \%$ by removing $4 \mathrm{ft}$ of the $11 \mathrm{ft}$ dry soil cover, when $k_{s}=0.15 \mathrm{Btu} /(\mathrm{hr})\left(\mathrm{ft}^{2}\right)\left({ }^{\circ} \mathrm{F} / \mathrm{hr}\right)$, $k_{c}=0.33 \mathrm{Btu} /(\mathrm{hr})\left(\mathrm{ft} \mathrm{C}^{2}\right)\left({ }^{\circ} \mathrm{F} / \mathrm{ft}\right)$ and $S=0.4 \mathrm{Btu} /(\mathrm{hr})\left(\mathrm{ft}{ }^{3}\right)$. 


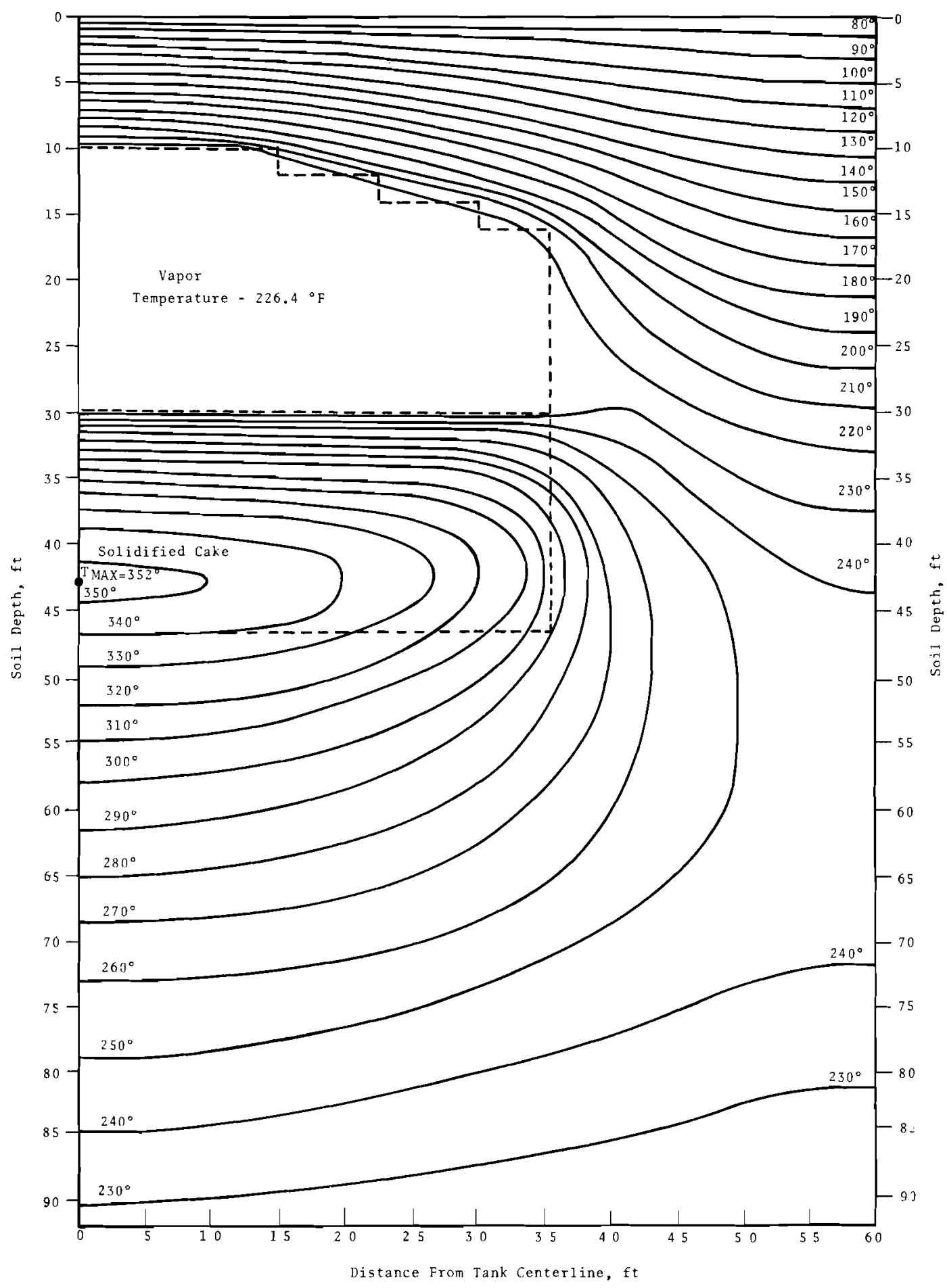

FIGURE 2. Temperatures Around an Underground waste Storage Tank Containing a solid cake. Soil Thermal Conductivity $=0.33 \mathrm{Btu} /(\mathrm{hr})\left(\mathrm{ft} \mathrm{t}^{2}\right)\left({ }^{\circ} \mathrm{F} / f t\right)$. 


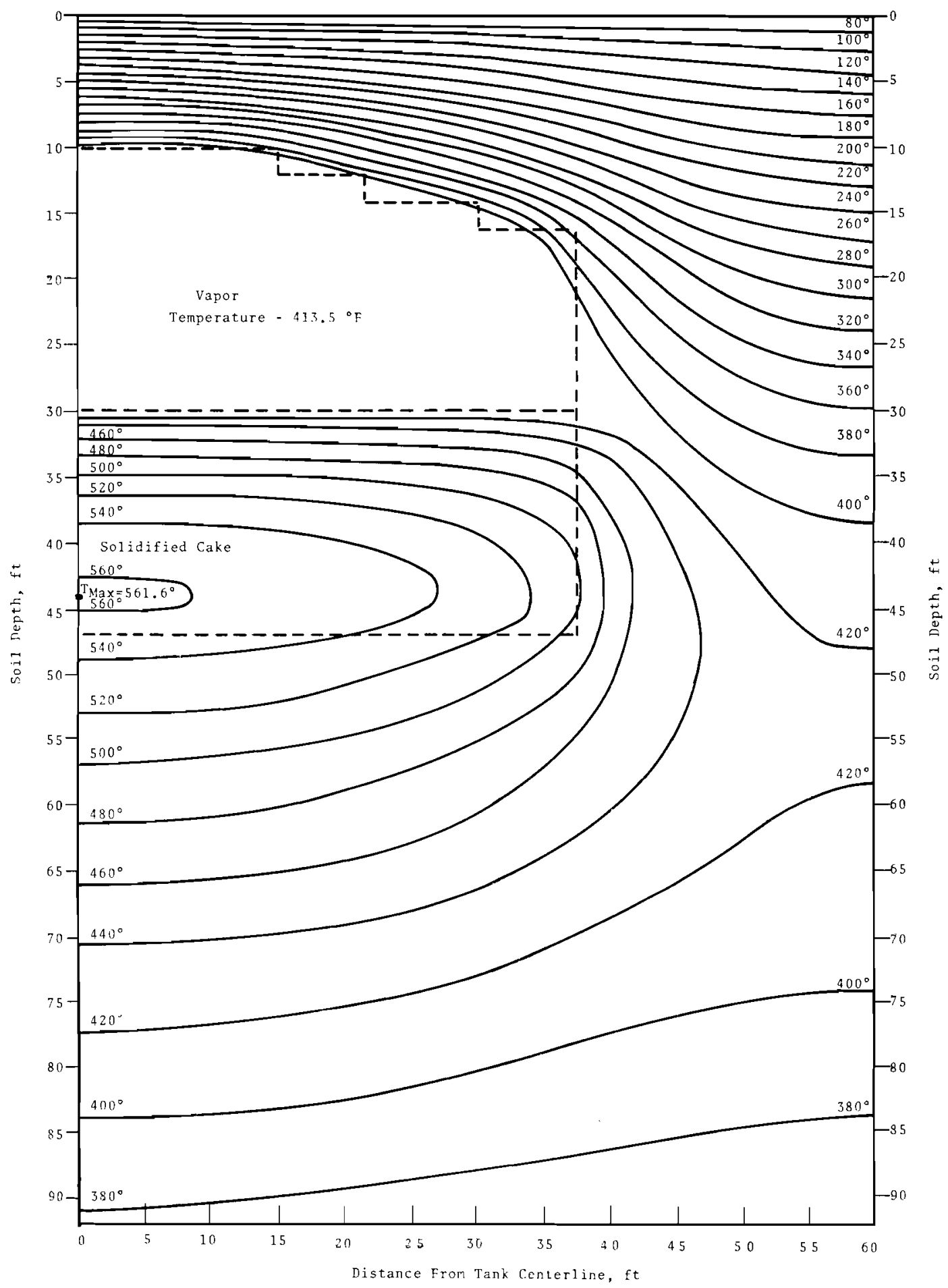

FIGURE 3. Temperatures Around an Underground Waste storage Tank Containing a solid Cake. Soil Thermal Conductivity $=0.15 \mathrm{Btu} /(\mathrm{hr})\left(f t^{2}\right)\left({ }^{\circ} \mathrm{F} / f t\right)$. 


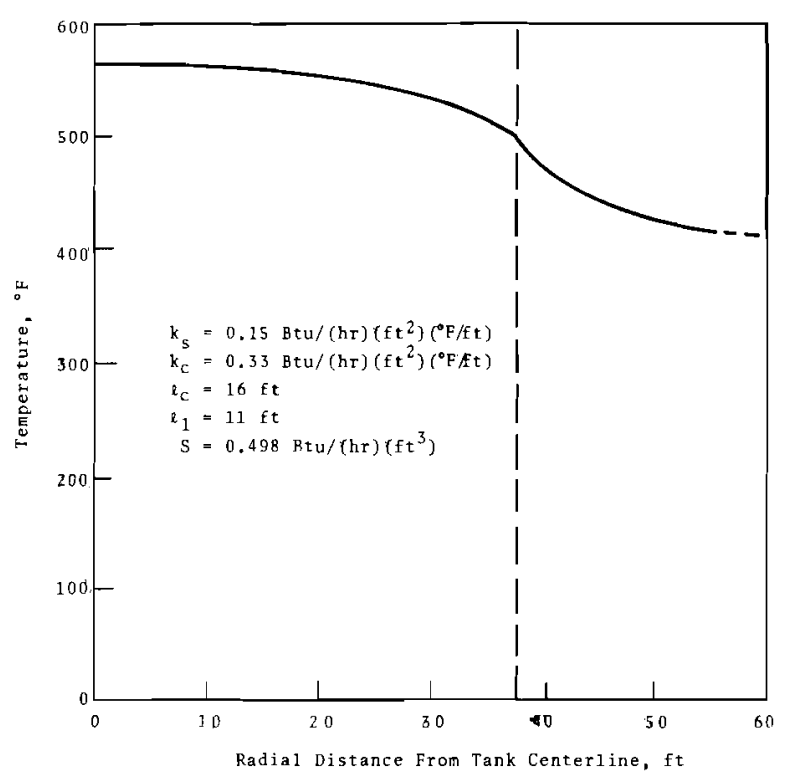

FIGURE 4. Temperature Profize in the Horizontal Plane of Maximum Temperature

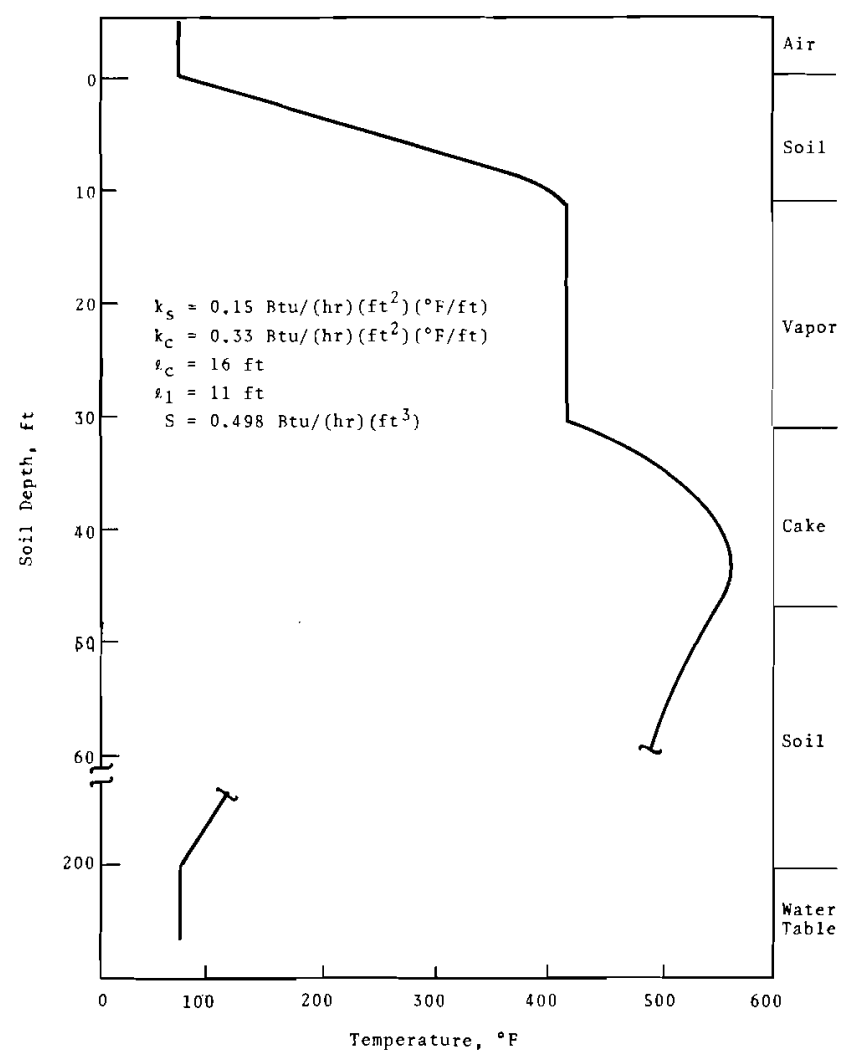
FIGURE 5. Temperature Profile in the Vertical Plane Along
the Axis of the Tank 


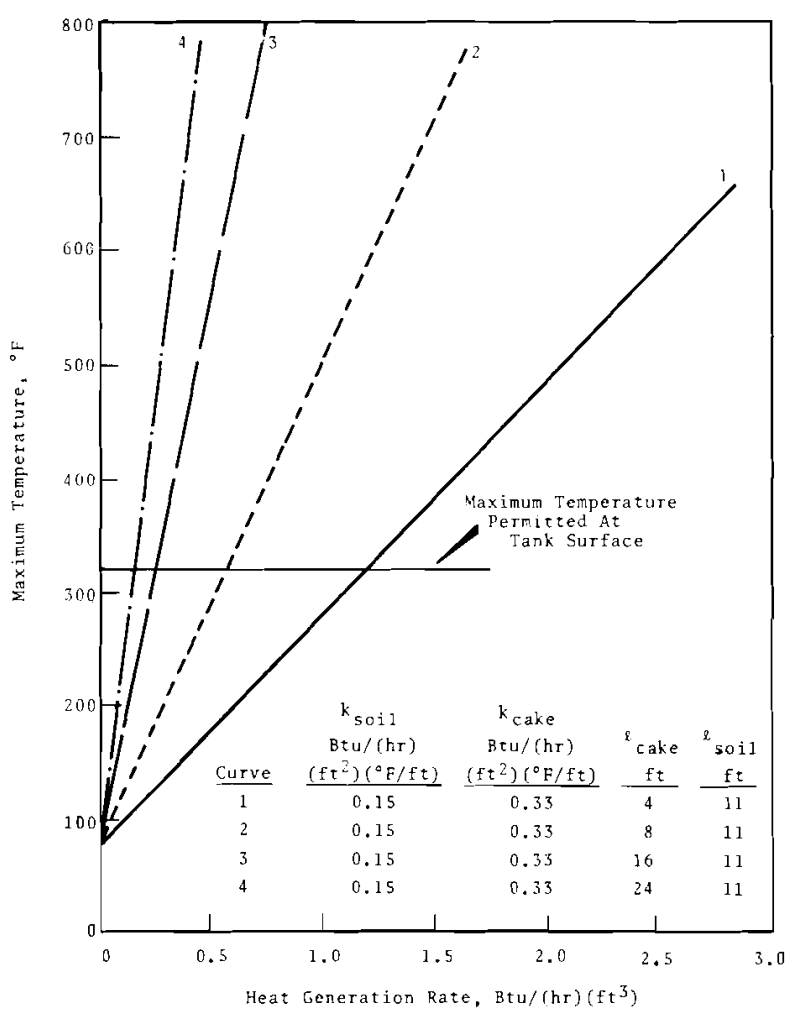

EIGURE 6. Maximum Temperature in Buried storage Tanks, Effect of Volumetric Heat Generation Rate

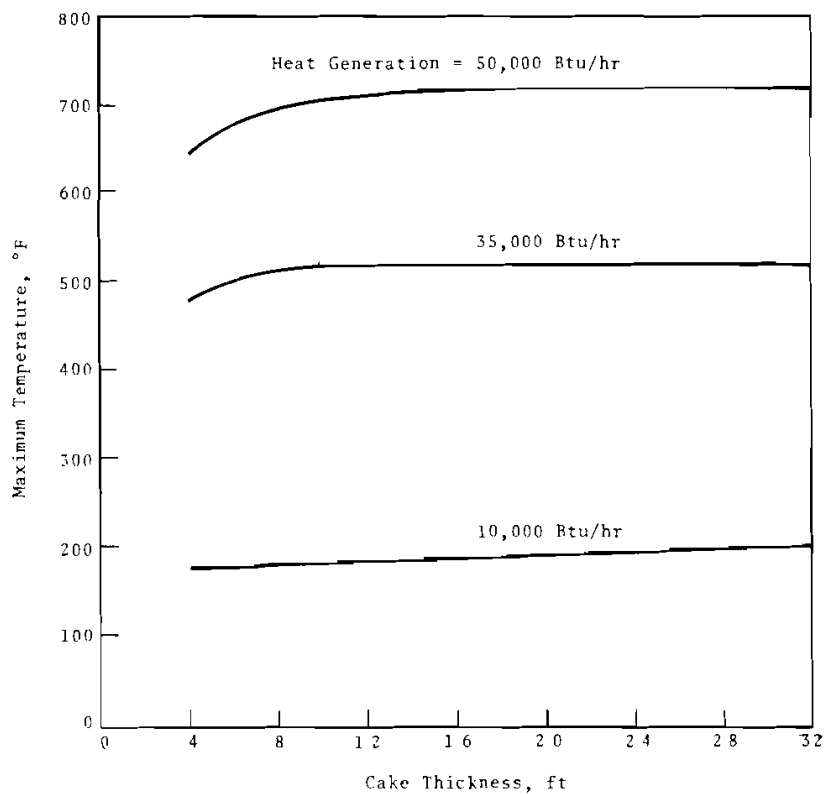

FIGURE 7. Heat Dissipation from Buried Radioactive Waste Storage Tanks (Effect of Cake Thickness) 
However, this might be enough to allow the tank to remain in service without exceeding the limits. One factor which must be taken into consideration before removing the soil is the loss of radiation protection. It may be necessary to leave the soil in place in order to have sufficient protection.

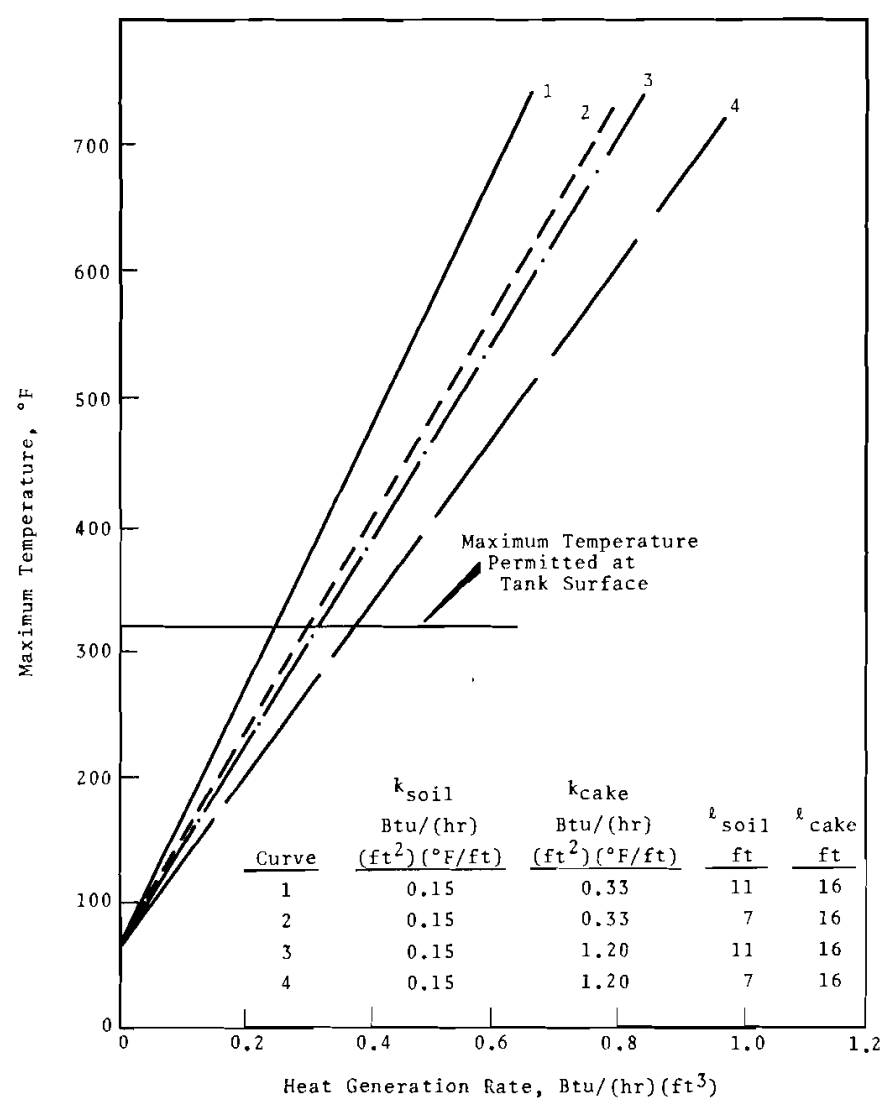

FIGURE 8. Maximum Temperature in Buried Waste Storage Tanks (Effect of Soil Cover Depth)

\section{EFFECT OF THERMAL CONDUCTIVITY}

An overall picture of the effect of thermal conductivity and total heat generation rate is shown in Figure 9. Although this is an unusual way of plotting the data, a great deal of information is presented in the figure. 
BNWL - 262

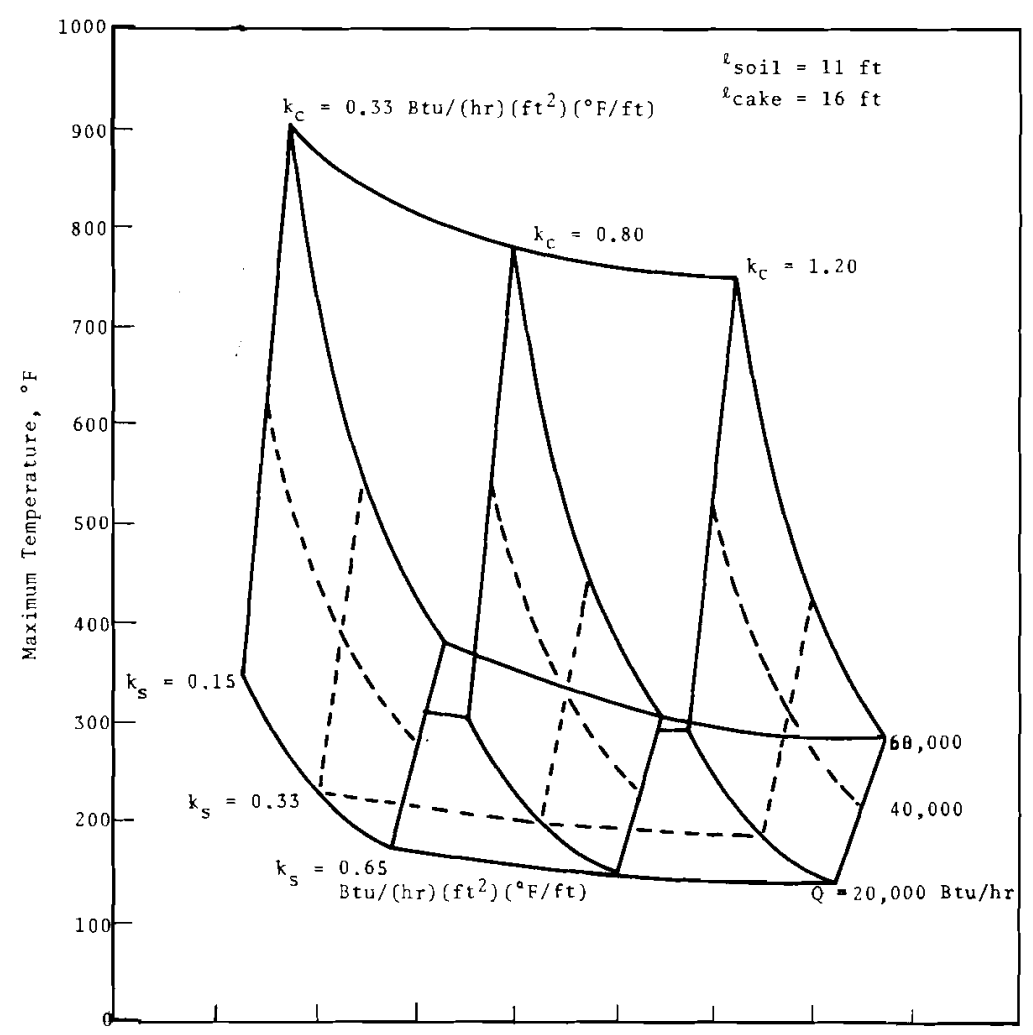

FIGURE 9. Maximum Temperature in Buried Waste Storage Tanks (Effect of Thermal Conductivity and Heat Generation)

Planes of constant soil and cake thermal conductivity along with curved surfaces of constant total heat generation are plotted against maximum cake temperature. Using $k_{c}=0.33$ $\mathrm{Btu} /(\mathrm{hr})\left(\mathrm{ft}{ }^{2}\right)\left({ }^{\circ} \mathrm{F} / \mathrm{ft}\right)$ as an example and a heat generation rate of $60,000 \mathrm{Btu} / \mathrm{hr}$, one may obtain the change in maximum temperature over the range of $k_{s}$ values from $0.15 B t u /(h r)\left(f t^{2}\right)$ $\left({ }^{\circ} \mathrm{F} / \mathrm{ft}\right)$ [dry soil] to $0.65 \mathrm{Btu} /(\mathrm{hr})\left(\mathrm{ft}{ }^{2}\right)\left({ }^{\circ} \mathrm{F} / \mathrm{ft}\right)$ [wet soil]. The temperature is $905^{\circ} \mathrm{F}$ for $\mathrm{k}_{\mathrm{s}}=0.15$ then drops to $550^{\circ} \mathrm{F}$ for $k_{s}=0.33$ and finally to $380^{\circ} \mathrm{F}$ for $k_{s}=0.65$. This shows the very important effect of soil thermal conductivity on the system.

When the cake thermal conductivity, $k_{c}$, is varied from 0.33 to 0.65 to $1.20 \mathrm{Btu} /(\mathrm{hr})\left(\mathrm{ft}{ }^{2}\right)\left({ }^{\circ} \mathrm{F} / \mathrm{ft}\right)$ and $\mathrm{k}_{\mathrm{s}}$ is held constant at $0.15 \mathrm{Btu} /(\mathrm{hr})\left(\mathrm{ft} \mathrm{C}^{2}\right)\left({ }^{\circ} \mathrm{F} / \mathrm{ft}\right)$, a change in temperature 
from 905 to 780 to $750^{\circ} \mathrm{F}$ is obtained. This change is appreciably smaller than that brought about by a variation in soil therma 1 conductivity.

The presented data is only for the case of a $16 \mathrm{ft}$ cake with an $11 \mathrm{ft}$ soil cover. Data for other geometries could be presented in the same manner.

Another way of correlating the temperatures is shown in Figure 10. Although too many variables are involved to make useful dimensionless correlations including all parameters, a limited dimensional correlation of the form

$$
\frac{k_{s}}{S}\left(T_{\text {MAX }}-T_{A}\right)=\phi\left(\frac{k_{c}}{k_{s}}, \ell_{c}\right)
$$

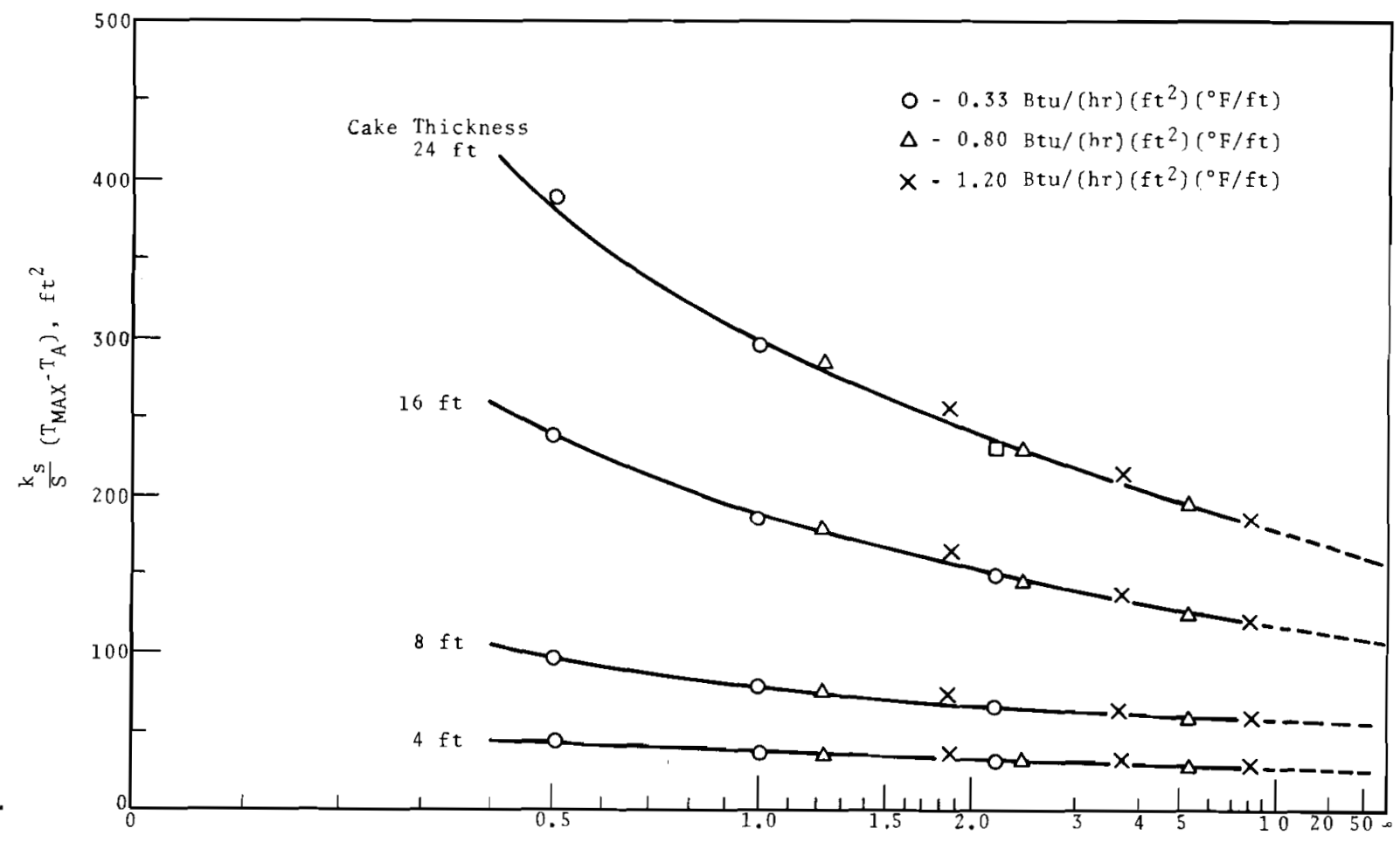

$\frac{k_{c}}{k_{s}}$, Ratio of Cake Thermal Conductivity to Soil Thermal Conductivity

FIGURE 10. Correlation of Maximum Temperature with Thermal conductivity 
is successful in presenting the effects of cake and soil thermal conductivities, cake thickness, and heat generation rate. As in Figure 9, the maximum temperature is strongly dependent on the soil thermal conductivity because the soil is a good insulator and is only a weak function of the cake thermal conductivity.

\section{APPROXIMATE MODEL}

DEVELOPMENT OF THE MODEL

Since the iterative technique proved to be difficult to adjust for changes in system geometry and consumed large amounts of computer time because of its complexity, an approximate model was developed to permit easier interpolation and variation of less important parameters. A sketch of the model is shown in Figure 11. The model is intended to calculate temperatures only along the axis of the tank and not a temperature distribution throughout the system as the iterative approach does.

A horizontal plane of maximum temperature across which no heat flows can be drawn through the heat-generating cake. All the heat is assumed to flow vertically through the cake so that a parabolic vertical temperature profile is present within the cake. Effective heat transfer coefficients for heat flow from the cake to the water table and to the atmosphere, are defined as follows:

$$
\begin{aligned}
\mathrm{U}_{\mathrm{U}}= & \text { the overall heat transfer coefficient for heat } \\
& \text { transfer from the top of the cake to the air, based } \\
& \text { on the cross sectional area of the cylindrical tank, } \\
& \text { Btu/(hr) } \left.{ }^{\circ} \mathrm{F}\right)\left(\mathrm{ft}^{2}\right) . \\
\mathrm{U}_{\mathrm{D}}= & \text { the overall heat transfer coefficient for heat } \\
& \text { transfer from the bottom of the cake to the water } \\
& \text { table, based on the cross sectional area of the } \\
& \text { cylindrical tank, Btu/(hr) } \left.{ }^{\circ} \mathrm{F}\right)(\mathrm{ft} 2) .
\end{aligned}
$$




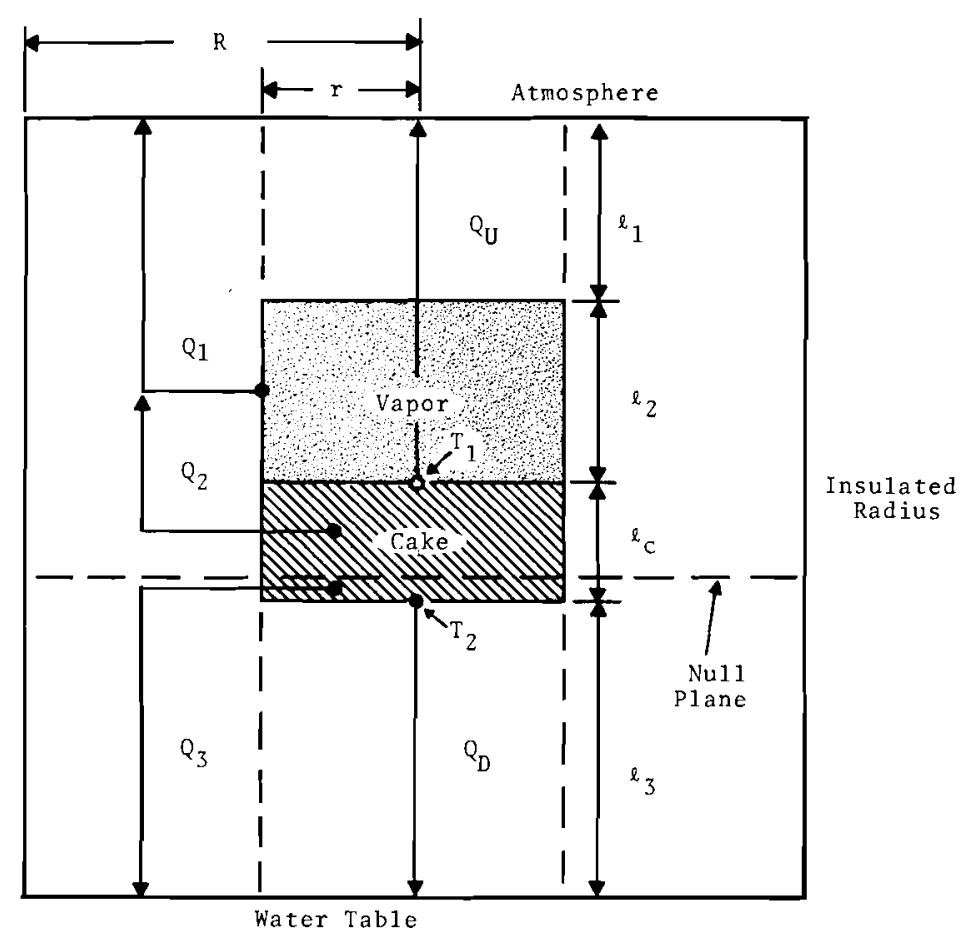

FIGURE 11. Approximate Model for Heat Flow in a Waste Tank Containing Solidified Wastes

The heat transfer coefficients are functions of the following variables:

$$
\begin{aligned}
\mathrm{U}_{\mathrm{U}} & =\mathrm{U}_{\mathrm{Q}_{1}}+\mathrm{U}_{\mathrm{Q}_{2}}+\mathrm{U}_{\mathrm{Q}_{\mathrm{U}}} \\
& =\phi\left(\mathrm{k}_{\mathrm{C}}, \mathrm{k}_{\mathrm{S}}, \mathrm{k}_{\mathrm{v}}, \mathrm{h}_{1}, \mathrm{~h}_{2}, \mathrm{~h}_{\mathrm{A}}, \mathrm{h}_{\mathrm{Q}_{1}}, \ell_{1}, \ell_{2}, \ell_{\mathrm{C}}, \mathrm{R}, \mathrm{r}\right) \\
\mathrm{U}_{\mathrm{D}} & =\mathrm{U}_{\mathrm{Q}_{3}}+\mathrm{U}_{\mathrm{Q}_{\mathrm{D}}}=\phi\left(\mathrm{k}_{\mathrm{s}}, \mathrm{R}, \mathrm{r}, \mathrm{l}_{3}\right)
\end{aligned}
$$

Derivations of the exact form of Equations (1) and (2) are given in Appendix B. A computer program for rapid calculation of the maximum temperatures is given in Appendix $C$. With the assumption that the water table temperature is equal to that of the air, the maximum temperature at the bottom of the cake is given by: 


$$
\mathrm{T}_{2}-\mathrm{T}_{\mathrm{A}}=\frac{\mathrm{Sl}_{\mathrm{c}}\left(1+\frac{\mathrm{U}_{\mathrm{U}}{ }^{\ell}{ }_{c}}{2 \mathrm{k}_{\mathrm{c}}}\right)}{\mathrm{U}_{\mathrm{U}}+\mathrm{U}_{\mathrm{D}}\left(1+\frac{{ }^{{ }_{c} \mathrm{U}_{U}}}{\mathrm{k}_{\mathrm{C}}}\right)}
$$

COMPARISON OF THE MODEL WITH ITERATIVE RESULTS

The correlation of maximum cake temperature with thermal conductivity was shown in Figure 10. The maximum temperature at the bottom of the tank next to the cake, which is slightly lower than the maximum cake temperature, may also be correlated in the same way. A comparison of the prediction of the approximate model with the results of the iterative calculation is made for the maximum tank bottom temperature in Figure 12. The greatest deviation is in the region of low cake thermal conductivity, which indicates that the model is not as good at predicting heat flow through the cake as it is for the soil. The high temperature prediction indicates that the assumed resistance to flow through the cake is too high. This seems to be consistent since the assumption of no heat losses out the side of the cake used in establishing the vertical temperature gradient through the cake would result in too high a resistance to flow in the cake. A statistical analysis of the difference between the results of the approximate model and the iterative calculations is given in Table $I$.

\section{STRATIFICATION OF HEAT-GENERATING FISSION PRODUCTS}

The effect of stratification of the heat-generating fission products can be predicted by the approximate model, as shown in the derivation in Appendix B. In Figure 13, for a $16 \mathrm{ft}$ cake, the maximum temperature at the bottom of the heat-generating layer is shown as a function of the fraction of the total cake occupied by the heat-generating layer with the total heat generation rate held constant at $70,700 \mathrm{Btu} / \mathrm{hr}$. Stratification might be present if the tank is filled intermittently with different age solutions or if precipitation of fission products occurred only during one stage of the solidification process. Localization to the top of the cake 


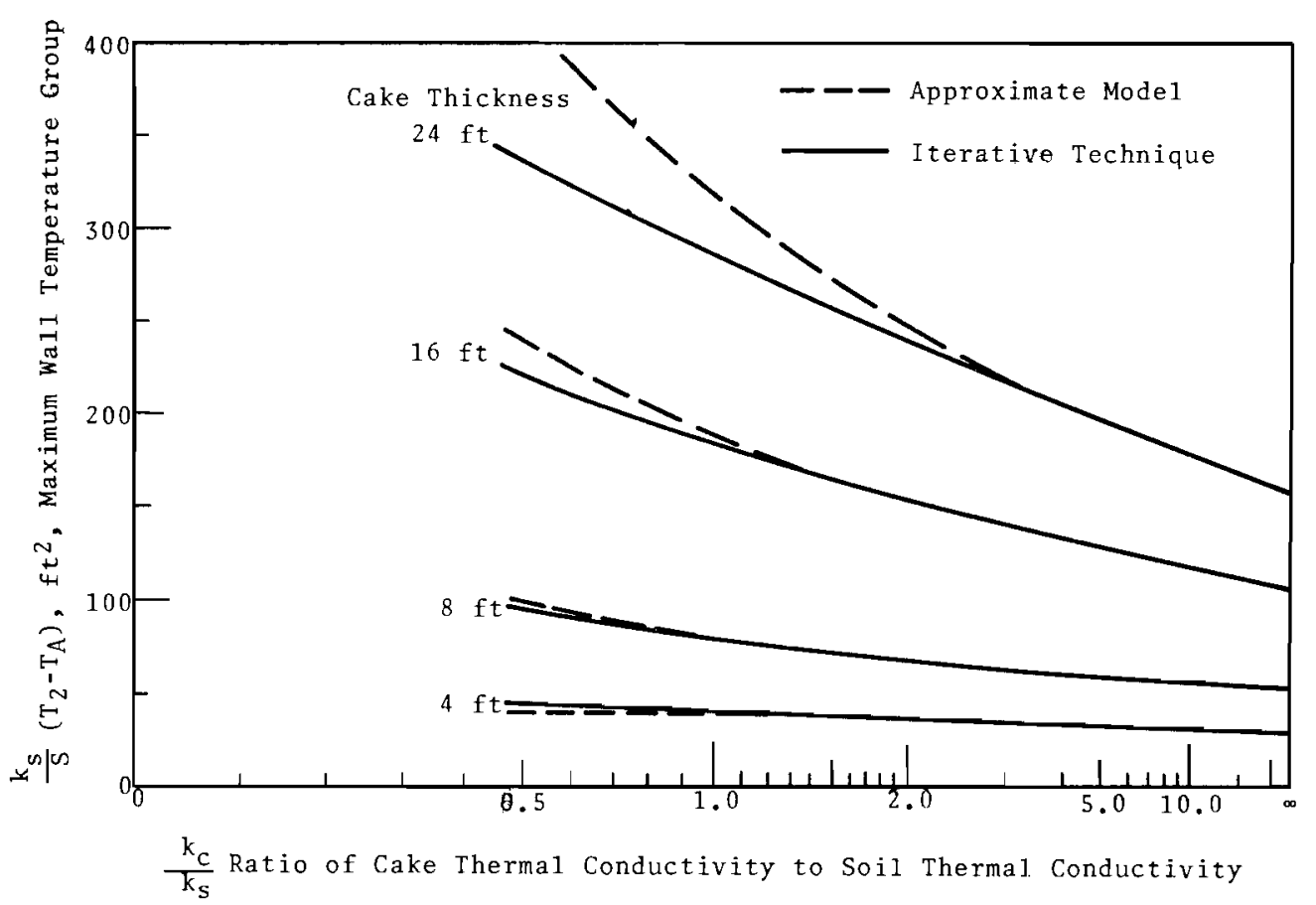

FIGURE 12. Comparison of Approximate Model with Iterative Calculations

TABLE I. Temperature at the Bottom of a Waste Storage Tank Summary of Comparison: Approximate Equation versus Iterative Method

The Iterative Method is Assumed Correct in these Comparisons, and the Errors are Calculated for the Temperature Rise Above Ambient.

\begin{tabular}{|c|c|c|c|c|c|}
\hline $\begin{array}{c}\text { Cake } \\
\text { Thickness, ft }\end{array}$ & $\begin{array}{l}\text { Number of } \\
\text { Cases } \\
\text { Iterative } \\
\text { Method(a) } \\
\end{array}$ & $\begin{array}{c}\text { Number of } \\
\text { Cases } \\
\text { Approximate } \\
\text { Equation } \\
\end{array}$ & $\begin{array}{c}\text { Bias of } \\
\text { The Mean } \\
\frac{\%}{0} \\
\end{array}$ & $\begin{array}{c}\text { Max. } \\
\text { Bias } \\
\frac{0}{6} \\
\end{array}$ & $\begin{array}{c}\text { Standard } \\
\text { Dev. from } \\
\text { Iterative } \\
\text { Case } \\
\frac{0}{6} \\
\end{array}$ \\
\hline 4 & 9 & 5 & -3.1 & -7.4 & 4.95 \\
\hline 8 & 14 & 10 & -1.4 & -4.3 & 2.33 \\
\hline 16 & 14 & 11 & -0.9 & +7.7 & 3.59 \\
\hline 24 & $\underline{12}$ & 9 & +4.6 & +12.8 & 7.39 \\
\hline Tota 1 & 49 & 35 & +0.6 & $\begin{array}{l}-7.4< \\
x<12 .\end{array}$ & $\begin{array}{ll}<x & 4.8 \\
.8 & \end{array}$ \\
\hline
\end{tabular}


BNWL -262

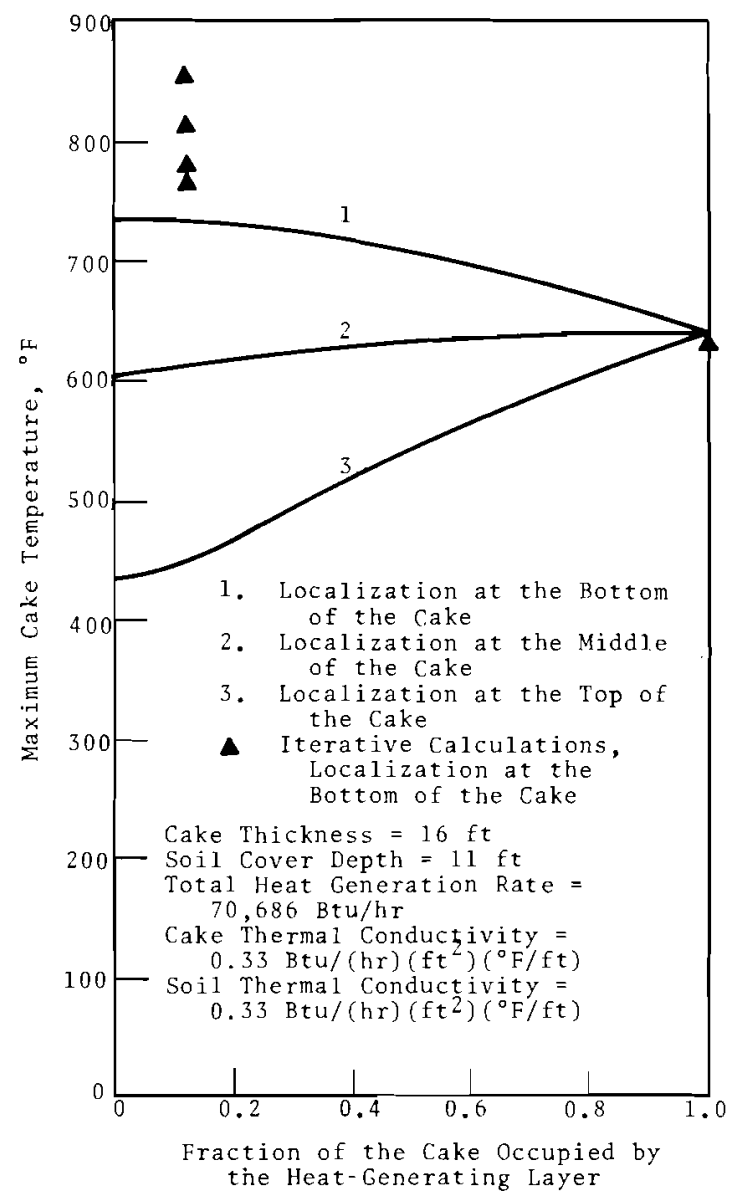

FIGURE 13. Effect of Stratification of Fission Products on the Maximum Cake Temperature

actually lowers the temperature, while stratification to the bottom of the cake produces a small temperature increase. The principal reason for the temperature change when heat sources are concentrated into layers is the difference in path length through the cake from the heat generation zone to the atmosphere. This is in contrast to localization of fission products toward a small spherical volume, for which the temperature becomes very high because the area for heat flow from the sphere is also reduced as the volume is decreased. 


\section{TEMPERATURE GRADIENTS IN THE CONCRETE LINER}

The steady-state temperature gradients across the concrete liner for various surfaces of the tank can be estimated from the heat fluxes across the surfaces. Comparison of the approximate calculations with the results of the iterative technique shows that the best estimate of the gradient through the liner at the bottom of the tank is made by assuming that all the heat which reaches the water table flows directly through the bottom of the tank. A comparison of the temperature gradients from the approximate equation and from the iterative method is given in Table II. The approximate gradients are in good agreement with the iterative method only for the concrete at the bottom and top of the tank. Much larger temperature gradients would be expected to occur during the transient heating period before steady-state is reached. USE OF THE APPROXIMATE MODEL

For a particular tank configuration, the conditions inside the tank have little effect on the overall external heat transfer coefficients, because the major resistance to heat flow is in the soil. The overall heat transfer coefficients $U_{U}$ and $U_{D}$ may be estimated in any one of three ways: (1) measurement of the top and bottom cake temperatures and the heat generation rate in an existing system, (2) calculation of the top and bottom cake temperatures by the iterative technique, or (3) direct estimation of the heat transfer coefficients by calculating the heat transfer coefficients $\mathrm{U}_{\mathrm{Q}_{1}}, \mathrm{U}_{\mathrm{Q}_{2}}, \mathrm{U}_{\mathrm{Q}_{3}}, \mathrm{U}_{\mathrm{Q}_{\mathrm{U}}}$, and $\mathrm{U}_{\mathrm{Q}_{\mathrm{D}}}$ for each f1ow path from the thermal properties of the system. Methods (1) and (2) involve the use of Equation (3) and the relationship between the top and bottom temperatures given in Equation (5) of Appendix B. 
TABLE II. Temperature Gradients in Concrete Liner

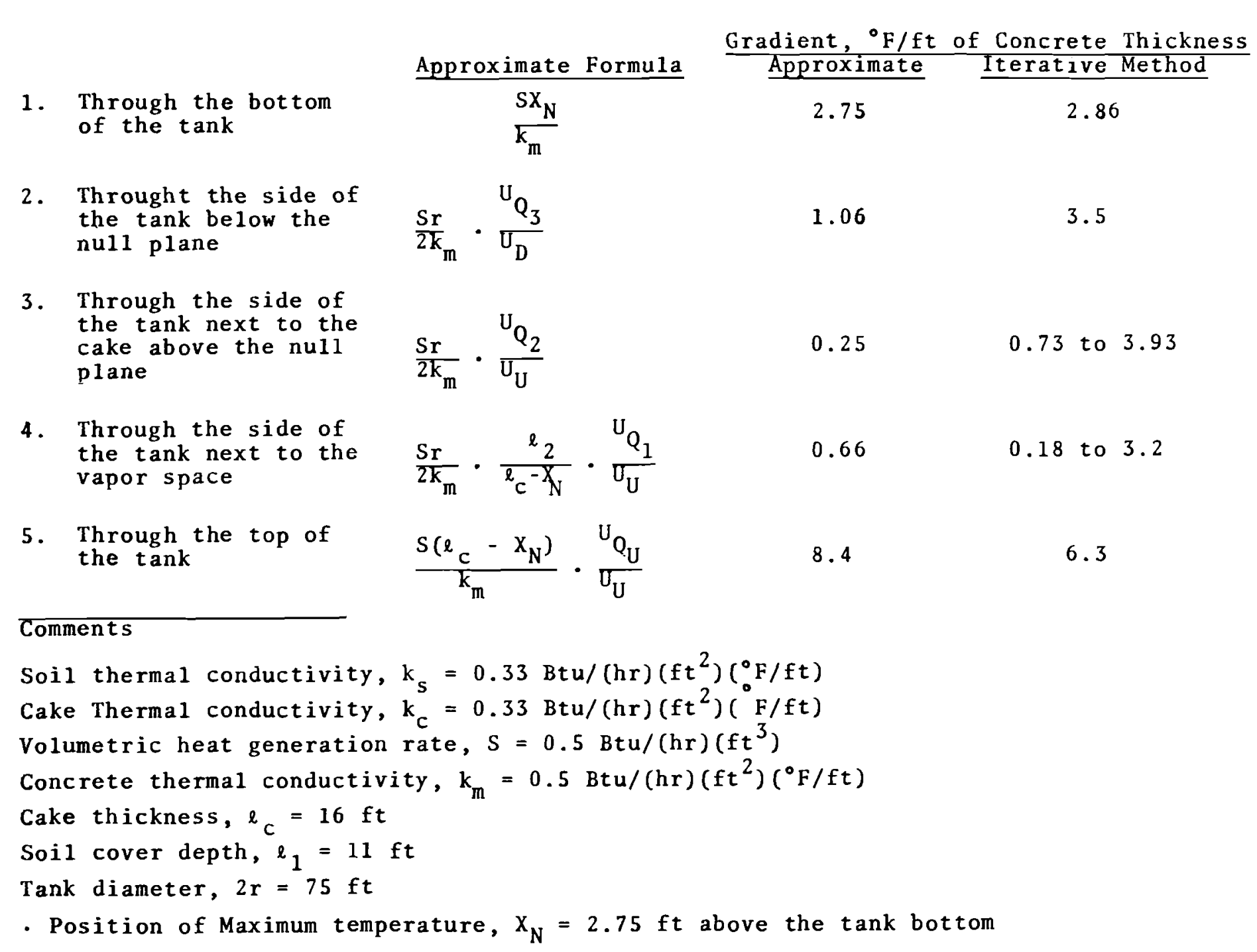

the tank next to the vapor space

$$
\frac{s\left(\ell_{c}-x_{N}\right)}{k_{m}} \cdot \frac{{ }_{Q_{U}}}{U_{U}}
$$

\section{Comments}

Soil thermal conductivity, $k_{s}=0.33 \mathrm{Btu} /(\mathrm{hr})\left(\mathrm{ft}{ }^{2}\right)\left({ }_{0}^{\circ} \mathrm{F} / \mathrm{ft}\right)$

Cake Thermal conductivity, $k_{c}=0.33 \mathrm{Btu} /(\mathrm{hr})\left(\mathrm{ft}^{2}\right)(\mathrm{F} / \mathrm{ft})$

Volumetric heat generation rate, $S=0.5 \mathrm{Btu} /(\mathrm{hr})\left(\mathrm{ft}^{3}\right)$

Concrete thermal conductivity, $\left.\mathrm{k}_{\mathrm{m}}=0.5 \mathrm{Btu} / \mathrm{hr}\right)\left(\mathrm{ft}{ }^{2}\right)\left({ }^{\circ} \mathrm{F} / \mathrm{ft}\right)$

Cake thickness, $\ell_{c}=16 \mathrm{ft}$

Soil cover depth, $\ell_{1}=11 \mathrm{ft}$

Tank diameter, $2 \mathrm{r}=75 \mathrm{ft}$

- Position of Maximum temperature, $X_{N}=2.75 \mathrm{ft}$ above the tank bottom 
The heat transfer coefficients $U_{U}$ and $U_{D}$ calculated by method (3) are correlated in Figure 14 as a function of soil thermal conductivity for several cake thicknesses and soil cover depths. Since they refer to conditions outside the cake, they are not a function of the cake thermal conductivity. The values of $U_{U}$ calculated by method (2) are also shown in Figure 14 for comparison.

Several example problems are given in Appendix $D$ to show how to calculate $U_{U}$ and $U_{D}$ and how to use them to vary conditions in the cake.

Direct use of the approximate model equations for ratios of (tank spacing/tank diameter) greater than 1.6 are not recommended because the proper heat flow paths and areas for flow are no longer the simple arithmetic averages used in the approximate model. Since it is difficult to determine the proper areas, a technique which estimates the heat flux escaping across the radius $R=1.6 \mathrm{r}(60 \mathrm{ft}$ radius for a $37.5 \mathrm{ft}$ radius tank) is used. 'The results of this technique are explained in the discussion of Figure 16 (p.29) and in Appen$\operatorname{dix} B$.

\section{GENERALIZED CORRELATIONS}

DIMENSIONAL ANALYSIS

The temperature at any given point in the system is a function of the following variables:

$$
\begin{aligned}
\mathrm{T}= & \phi\left(\mathrm{h}_{1}, \mathrm{~h}_{2}, \mathrm{~h}_{\mathrm{A}}, \mathrm{h}_{\mathrm{Q}_{1}}, \mathrm{k}_{\mathrm{c}}, \mathrm{k}_{\mathrm{S}}, \mathrm{k}_{\mathrm{v}}, \ell_{1}, \ell_{2}+\ell_{\mathrm{c}}, \ell_{3}, \ell_{\mathrm{c}},\right. \\
& \left.\mathrm{r}, \mathrm{R}, \mathrm{S}, \mathrm{T}_{\mathrm{A}}, \mathrm{T}_{\mathrm{W}}\right)
\end{aligned}
$$

In dimensionless form, this might be represented as follows; if $r$, the tank radius, is taken as the reference dimension, $\mathrm{T}_{\mathrm{A}}$ the atmospheric temperature is the reference temperature and $\mathrm{k}_{\mathrm{s}}$ is the reference thermal property. 


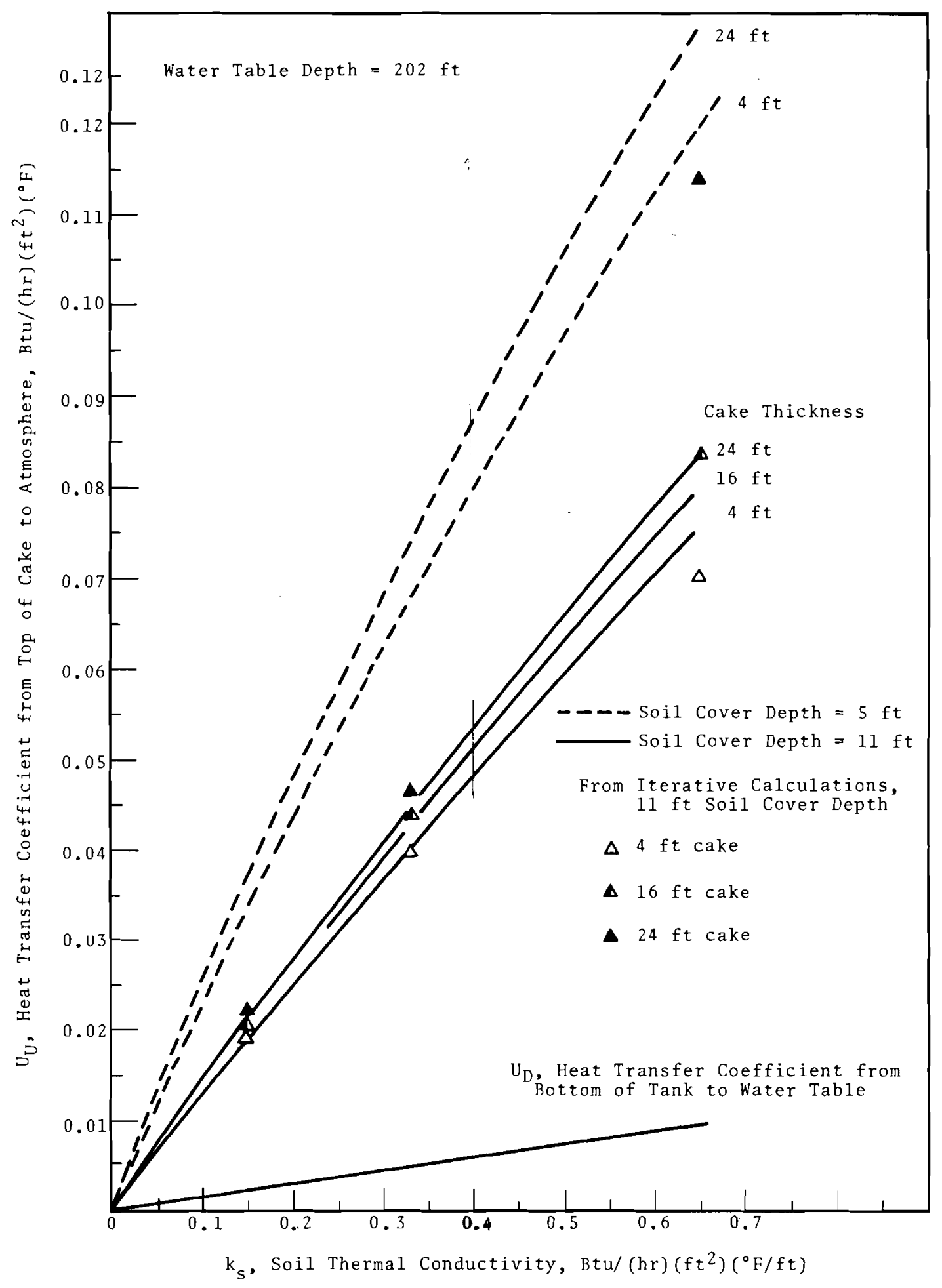

FIGURE 14. Overall Heat Transfer Coefficients 


$$
\begin{aligned}
\frac{k_{S}\left(T-T_{A}\right)}{S r^{2}}= & \Phi\left[\frac{h_{1} r}{k_{S}}, \frac{h_{2} r}{k_{S}}, \frac{h_{A} r}{k_{s}}, \frac{h_{Q_{1}}}{k_{s}}, \frac{k_{c}}{k_{s}}, \frac{k_{v}}{k_{s}}, \frac{\ell_{1}}{r}, \frac{\ell_{2}+{ }^{\ell}{ }_{c}}{r}, \frac{\ell_{3}}{r}, \frac{\ell_{c}}{r}\right. \\
& \left.\frac{R}{r}, \frac{k_{S}\left(T_{A}-T_{W}\right)}{S r^{2}}\right] .
\end{aligned}
$$

Using twelve independent dimensionless groups in Equation (5) is little better than having the sixteen independent variables listed in Equation (4). The next step of simplification involves neglecting changes in variables which have little effect on the temperature. Thus, one may hold the heat transfer coefficients $h_{1}, h_{2}, h_{A}, h_{Q_{1}}$ and the vapor thermal conductivity $\mathrm{k}_{v}$ constant and set $T_{W}=T_{A}$ to obtain Equation (6).

$\frac{\mathrm{k}_{\mathrm{s}}\left(\mathrm{T}-\mathrm{T}_{\mathrm{A}}\right)}{\mathrm{Sr^{2 }}}=\Phi\left[\frac{\mathrm{k}_{\mathrm{c}}}{\mathrm{k}_{\mathrm{s}}}, \frac{\ell_{1}}{\mathrm{r}}, \frac{\ell_{2}+\ell_{\mathrm{c}}}{\mathrm{r}}, \frac{\ell_{3}}{\mathrm{r}}, \frac{\ell_{\mathrm{c}}}{\mathrm{r}}, \frac{\mathrm{R}}{\mathrm{r}}\right]$

The next degree of simplification involves fixing the tank radius $r$ at $37.5 \mathrm{ft}$ and correlating maximum temperature with the major variables as shown in Equation (7).

$\frac{k_{S}\left(T-T_{A}\right)}{S}=\Phi\left[\frac{k_{C}}{k_{S}}, \ell_{1}, \ell_{1}+\ell_{c}, \ell_{3}, \ell_{c}, R\right]$.

In the tank farms operated by Isochem at Hanford, the tank height $\left(\ell_{2}+\ell_{C}\right)$, the tank spacing $(2 R)$, and the distance from the tank bottom to the water table $\left(l_{3}\right)$ are usually fixed so that the correlation reduces to Equation (8),

$\frac{\mathrm{k}_{\mathrm{S}}\left(\mathrm{T}-\mathrm{T}_{\mathrm{A}}\right)}{\mathrm{S}}=\Phi\left[\frac{\mathrm{k}_{\mathrm{c}}}{\mathrm{k}_{\mathrm{S}}, \ell_{1}, \ell_{\mathrm{C}}}\right]$.

Varying degrees of complexity are involved in the correlations presented here. All the variables present in Equation (4) are included in the approximate model, Equation (7) includes 
the major variables generally present in tank farm systems, but Equation (8) includes only the variables involved in practical analyses of the existing Hanford tank farms. The major independent variables at Hanford are soil cover depth, cake thickness, soil thermal conductivity, cake thermal conductivity, and heat generation rate. Since the tank radius $r$ is fixed, a new reference dimension may be used to reduce the number of groups in Equation 8. Taking the cake thickness $\ell_{c}$ as the new reference dimension,

$\frac{\mathrm{k}_{\mathrm{S}}\left(\mathrm{T}-\mathrm{T}_{\mathrm{A}}\right)}{\mathrm{S} \ell_{\mathrm{C}}^{2}}=\Phi\left[\frac{\mathrm{k}_{\mathrm{C}}}{\mathrm{k}_{\mathrm{S}}}, \frac{\ell_{1}}{\ell_{\mathrm{C}}}\right]$.

This correlation has been made with results of the iterative technique for an assumed form of the function $\Phi$ to give

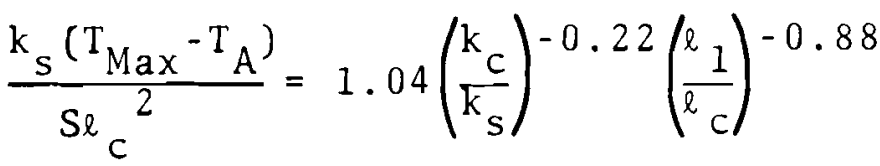

The standard deviation for a least squares fit of all the results of the iterative calculations over the region of application $7 \leq \ell_{1} \leq 11,0 \leq \ell_{\mathrm{c}} \leq 24,0.33<\mathrm{k}_{\mathrm{c}}-1.20,0.15 \leq \mathrm{k}_{\mathrm{s}}$ $\leq 0.65$ is $+8.6 \%$ to $-7.9 \%$ from the values calculated calculated by Equation (10). The approximate effect of each independent variable on the maximum temperature is found by rearranging Equation $(10)$.

$$
\mathrm{T}_{\text {MAX }}-\mathrm{T}_{\mathrm{A}}=1.04 \mathrm{~S} \mathrm{k}_{\mathrm{s}}^{-0.78} \mathrm{k}_{\mathrm{c}}^{-0.22} \ell_{\mathrm{c}}^{1.22} \ell_{1}^{0.88}
$$

CORRELATION OF MAJOR VARIABLES

If the tank diameter is fixed at $75 \mathrm{ft}$, Equation (7) applies:

$$
\frac{k_{s}\left(T-T_{A}\right)}{S}=\Phi\left[\frac{k_{c}}{k_{S}}, \ell_{1}, \ell_{2}+\ell_{C}, \ell_{3}, \ell_{c}, R\right]
$$


To illustrate the effect of each variable, plots of $k_{S}\left(T-T_{A}\right) / S$ versus $\ell_{1}, \ell_{2}+\ell_{c}, \ell_{3}$, $\ell_{c}$, or $R$ individually can then be made with $k_{c} / k_{s}$ as a parameter and the remaining variables held constant at fixed values. Such effects, given in Figures 15, 16 , 19 (p. 34) and 20 (p. 35) were calculated by the approximate mode1. The influence of cake thickness, $\ell_{c}$, has previously been illustrated in Figures 10 and 12 .

The dimensional plots may be converted to other tank radii by using the fact that the ratio of each dimension factor in Equation ( 6 ) to the reference dimersion, $r$, must be kept constant. Thus, if the tank radius, $r$, is changed to $r$, the new variables and fixed parameters in Equation (7) and Figures $10,12,15,16,19$, and 20 are given by:

$$
\begin{aligned}
& \ell_{1}^{\prime}=\ell_{1^{\prime}} \mathrm{r}^{\prime} / \mathrm{r} ; \ell_{2}^{\prime}+\ell_{c}^{\prime}=\left(\ell_{2}+\ell_{c}\right) \mathrm{r}^{\prime} / \mathrm{r} ; \\
& \ell_{3}^{\prime}=\ell_{3} \mathrm{r}^{\prime} / \mathrm{r} ; \ell_{c}^{\prime}=\ell_{c} \mathrm{r}^{\prime} / \mathrm{r} ; \text { and } \mathrm{R}^{\prime}=\mathrm{Rr} / \mathrm{r} .
\end{aligned}
$$

Example 6 of Appendix D illustrates this procedure.

\section{EFFECT OF SOIL COVER DEPTH}

The effect of soil cover depth on the maximum temperature at the bottom of a $16 \mathrm{ft}$ cake as calculated by the approximate model is shown in Figure 15. It is seen that the removal of soil cover can lower the maximum temperatures appreciably. However, the increased gamma radiation through the layers of soil may dictate that a relatively thick layer be maintained, as was mentioned in the discussion of Figure 8 .

EFFECT OF TANK SPACING

The effect of tank spacing on the maximum tank bottom temperature for a $16 \mathrm{ft}$ cake is shown in Figure 16. All 


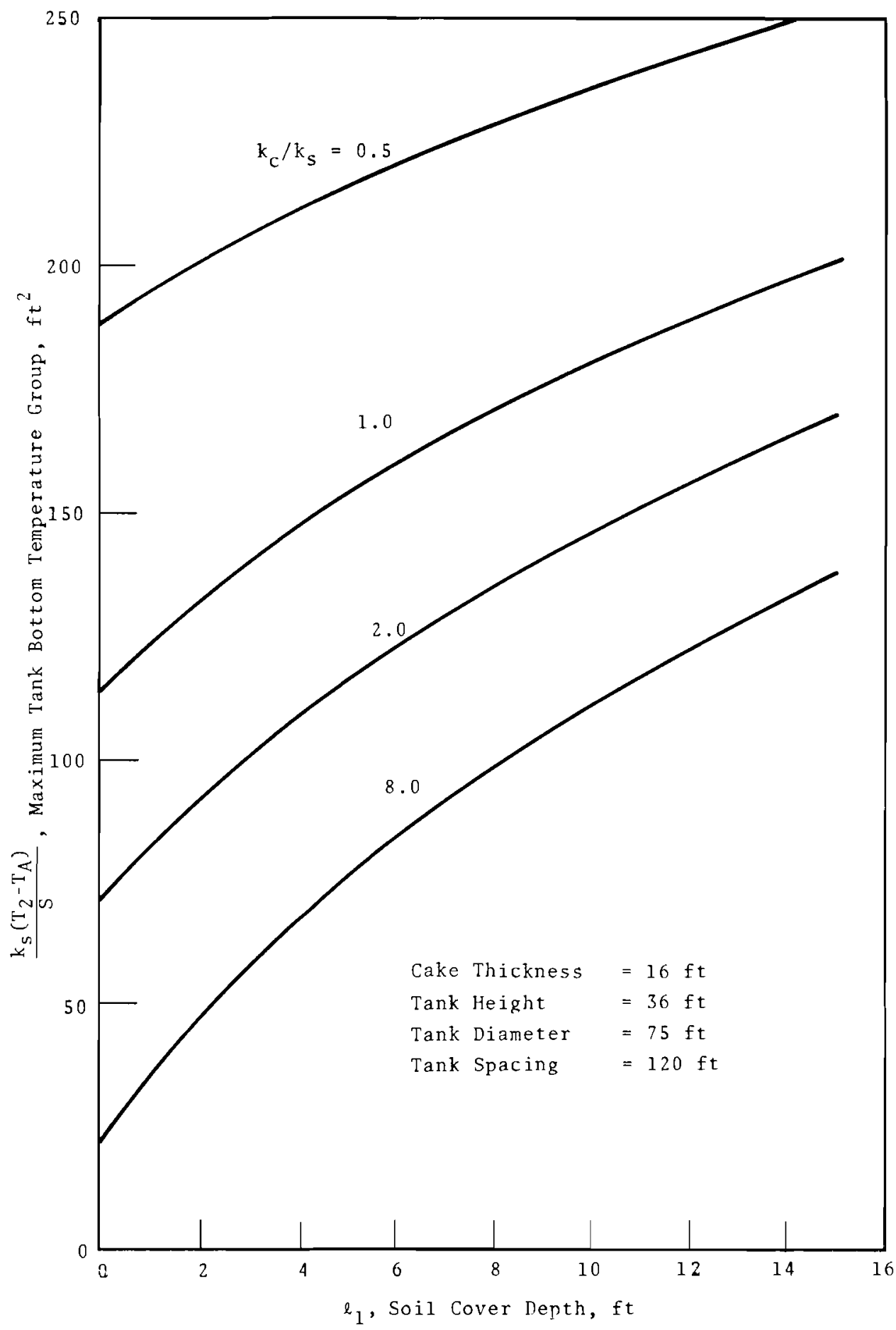

FIGURE 15. Maximum Temperature at the Bottom of a Storage Tank, Effect of Soil Cover Depth 


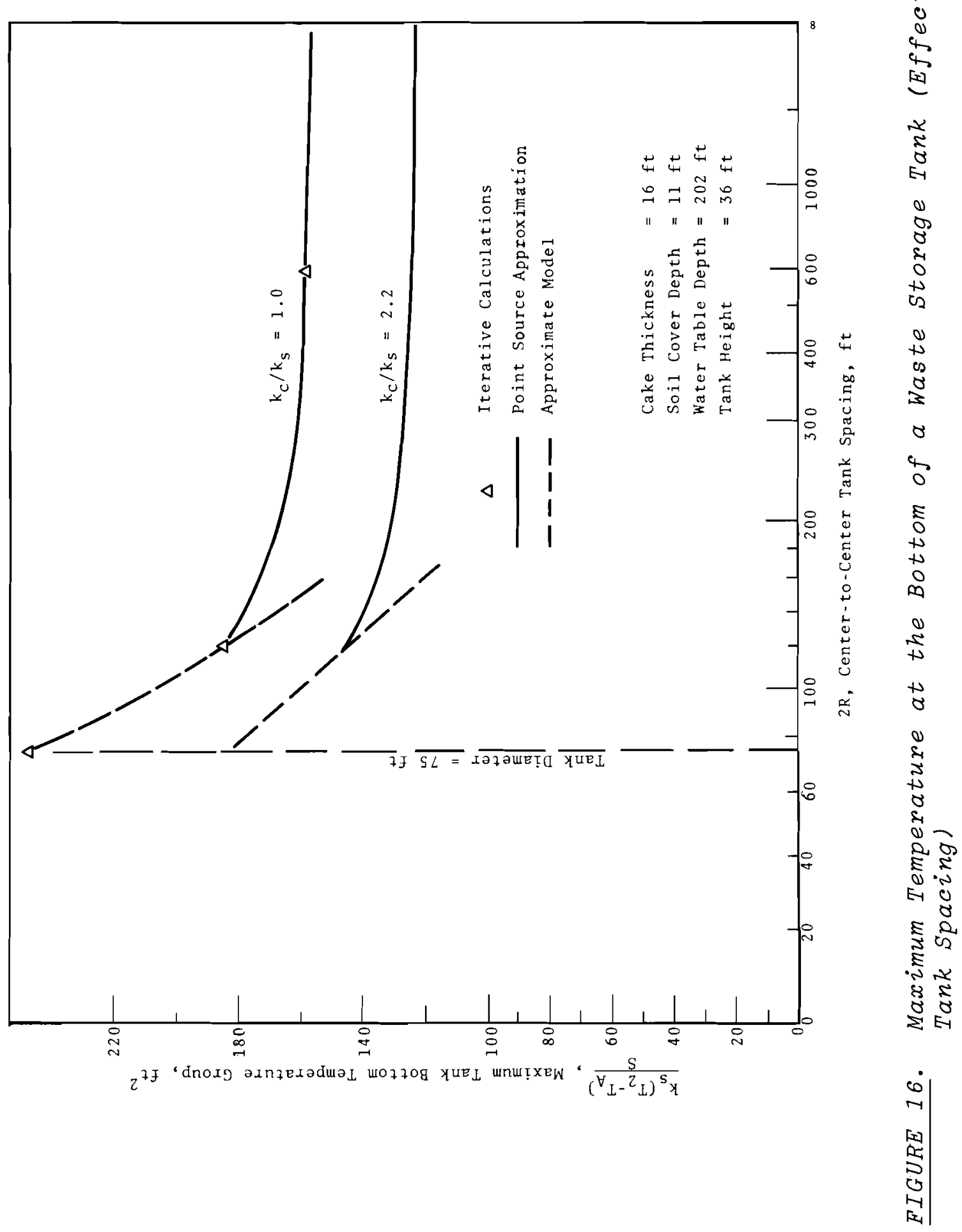


calculations were made using an insulated radius, $R$, around the tank to simulate a tank farm. This is not strictly correct because rectangular tank spacing would result in an insulated rectangular shell in an infinite size tank farm and equilateral triangular spacing would result in an insulated hexagonal shel1 in an infinite size tank farm of identical tanks. Three points corresponding to insulated radii of $37.5,60$, and $300 \mathrm{ft}$ are available from the iterative calculations. The approximate model is used to calculate the temperature for less than $120 \mathrm{ft}$ center-to-center spacing. For larger radii, it is necessary to use the point source correction to the approximate mode1 dis cussed in Appendix $B$ to estimate the heat flux across the $60 \mathrm{ft}$ radius. The effect of tank spacing is small with spacings larger than $250 \mathrm{ft}$.

A comparison of the vertical and horizontal temperature profiles in a single tank and one in a matrix, or tank farm, is made in Figures 17 and 18 for a $2 \mathrm{ft}$ cake generating 32,800 Btu/hr. A temperature of $408^{\circ} \mathrm{F}$ is reached in the cake for the tank within a tank farm as specified, while the cake in the solitary tank reaches only $332^{\circ} \mathrm{F}$. The close approach to ambient temperature of $70^{\circ} \mathrm{F}$ at radii greater than $200 \mathrm{ft}$ shows that the assumed boundary condition of no radial heat flow across a $300 \mathrm{ft}$ radius gives a good approximation to a single tank in an infinite radius medium.

Comparison of the vertical temperature profiles along the axes of tanks in the two systems shows that the temperature gradients toward the soil surface and the water table are quite similar, although much more heat flows radially in the larger system. For the $60 \mathrm{ft}$ insulated radius, $85.6 \%$ of the heat generated goes to the atmosphere and the remainder to the water table. For the solitary tank, $68.5 \%$ of the heat is distributed 


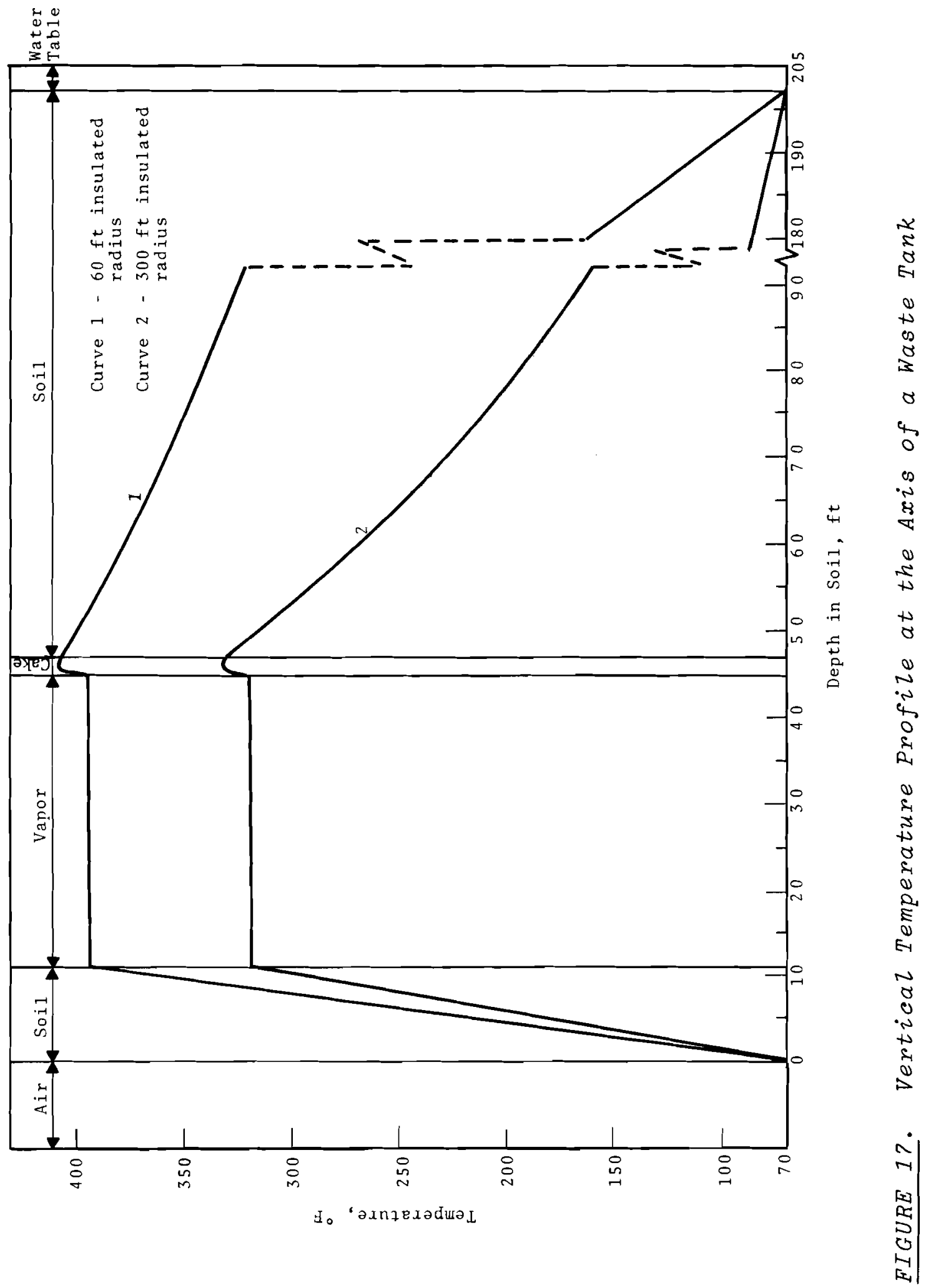




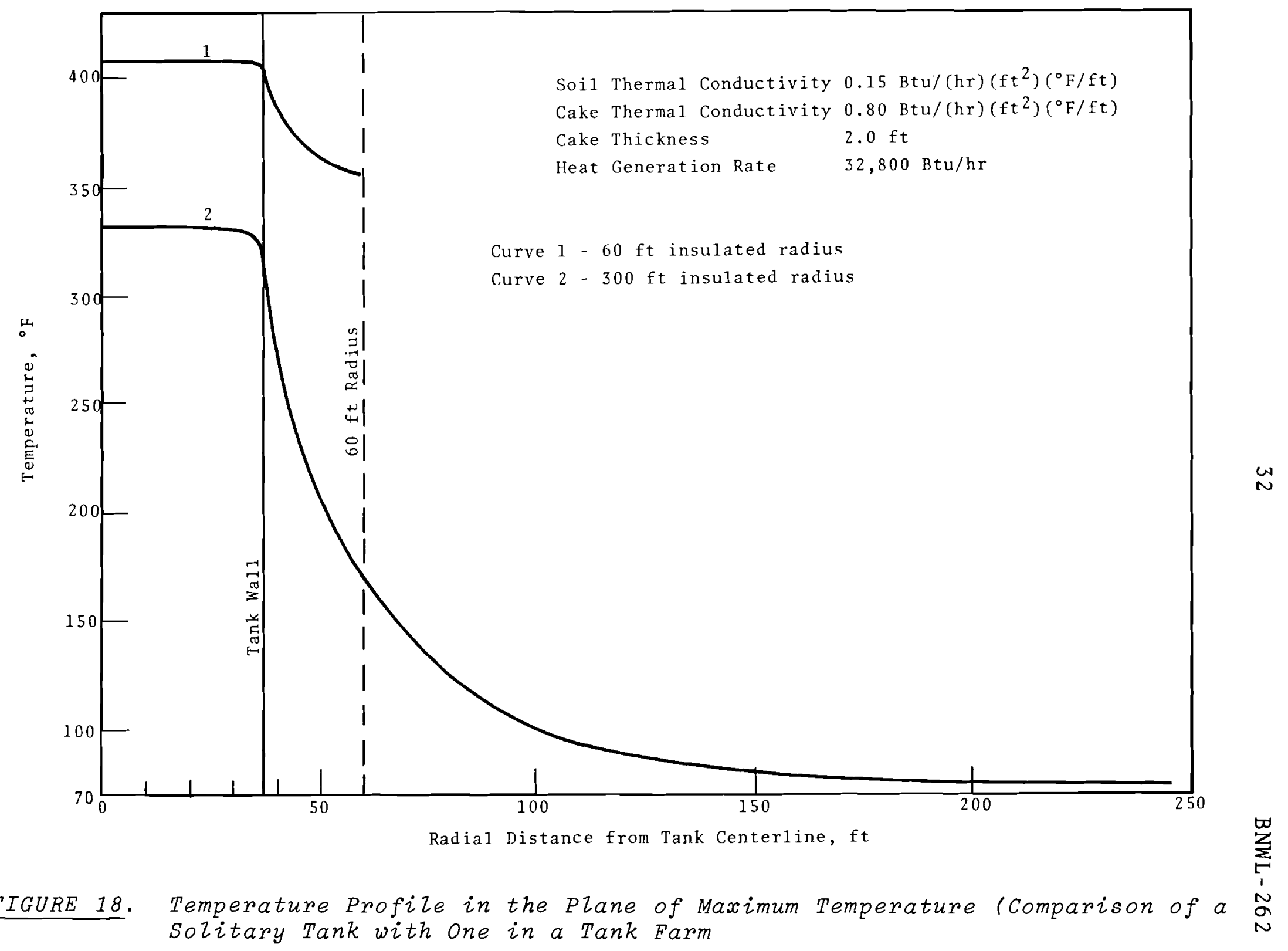


to the atmosphere and the water table within the $60 \mathrm{ft}$ radius and the remainder outside this radius. The split between the atmosphere and the water table is the same as for the tank with $60 \mathrm{ft}$ insulated radius.

\section{EFFECT OF WATER TABLE DEPTH}

In Figure 19, the water table depth is shown to have a small effect in arid surroundings because very little heat is conducted to it. However, when the water table approaches the tank bottom, appreciable heat flows to it and the assumption that the water table is a sink with no thermal resistance is probably unjustified.

\section{EFFECT OF TANK HEIGHT}

Within limits, the height-to-diameter ratio of the tank has no effect on the maximum temperature as is shown in Figure 20. The higher the tank the more heat is lost out the sides through the vapor space, but this is compensated by longer flux paths to the surface. Since the cake thickness is held constant at $16 \mathrm{ft}$ in Figure 20 , a $16 \mathrm{ft}$ deep tank has no vapor space and a $36 \mathrm{ft}$ deep tank has a $20 \mathrm{ft}$ vapor space. Since the soil cover depth remains constant for the correlation, increasing the tank height means lowering the tank bottom. 


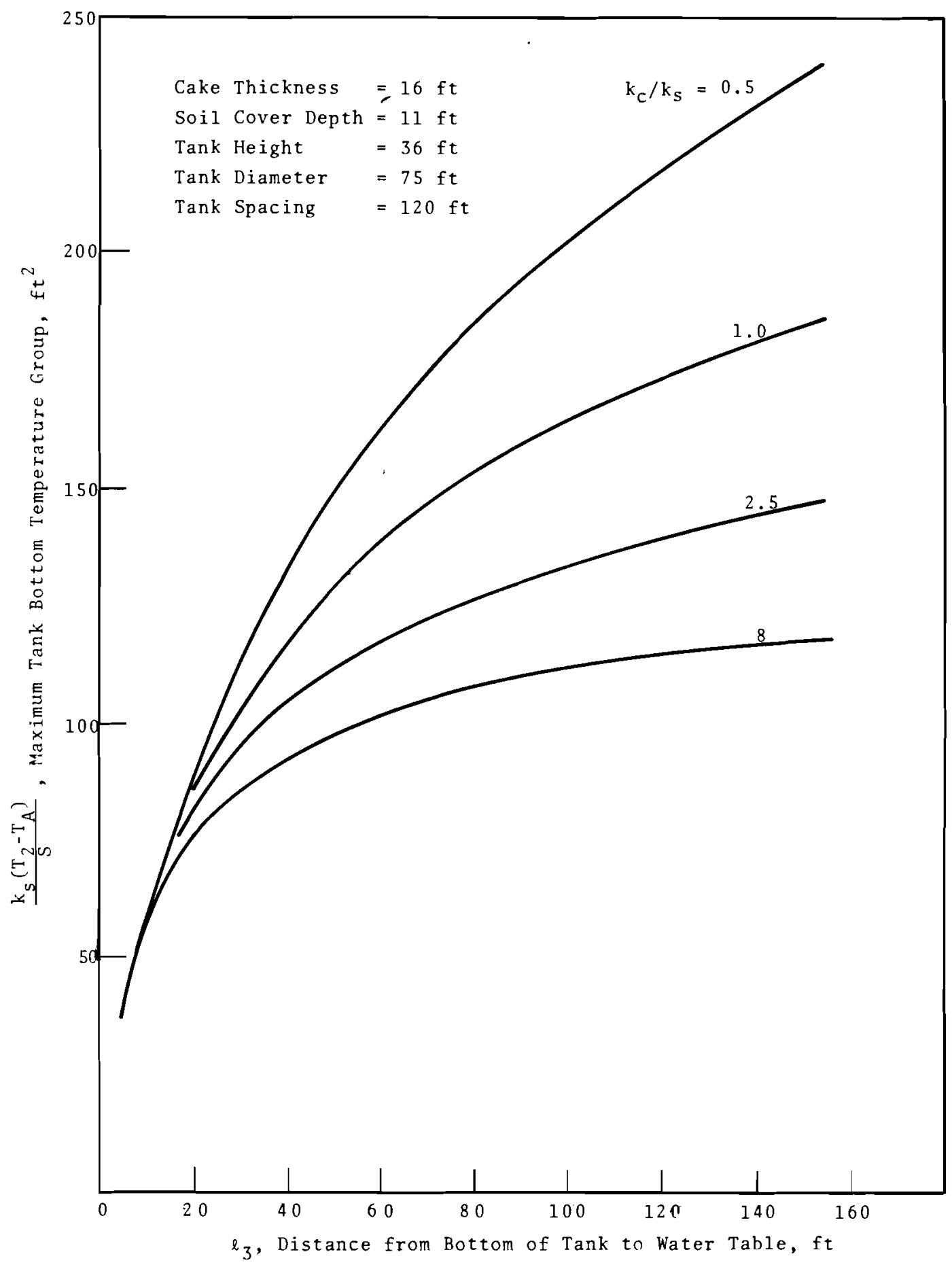

FIGURE 19. Maximum Temperature at the Bottom of a Storage Tank Containing Solidified Wastes, Effect of Water Table Depth 


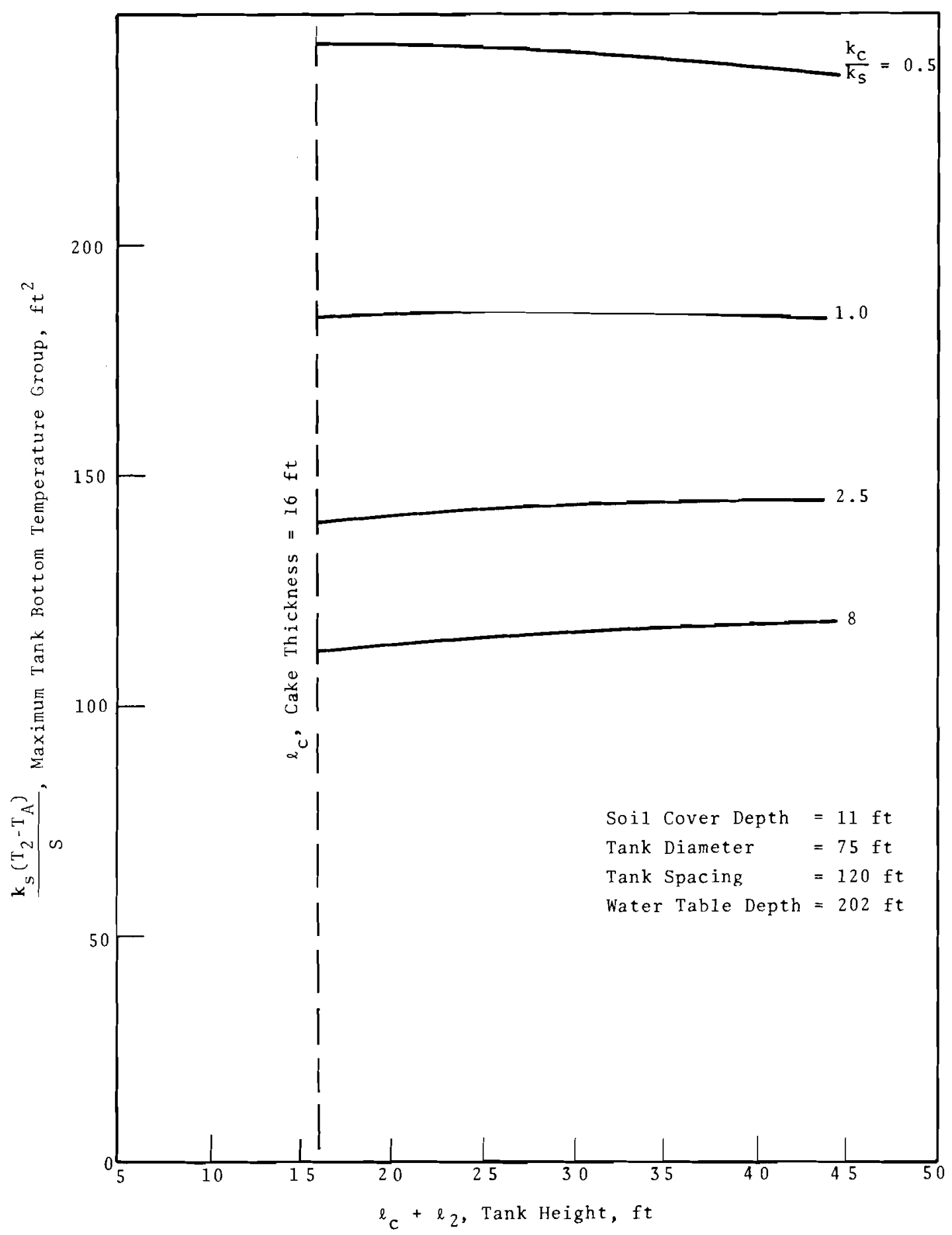

FIGURE 20. Maximum Temperature at the Bottom of a Waste Storage Tank (Effect of Tank Height) 


\section{ACKNOWLEDGMENT}

This work was performed under the guidance of $W$. H. Swift, manager, Engineering Development Unit, Chemical Development Section, Chemistry Laboratory, BNW.

We are grateful to W. V. DeMier, Chemical Development, for writing a computer program for the approximate model and to G. E. Lysher and J. R. Nance for producing many of the original graphs used in the report. 
BNWL - 262

\section{APPENDIX A}

RESULTS OF ITERATIVE CALCULATIONS 


\section{APPENDIX A \\ RESULTS OF ITERATIVE CALCULATIONS}

For proper use of Program 001 the following input information is required:

- Area, volume, centroid location of each node

- Material type of each node

- Thermal conductivity of each material type

- Heat generation rate

- Sink temperatures and locations

- Film coefficients and locations

- Acceptable error 1 imits

- Running time for each case

A simplied flow diagram and typical computer print-out along with the computer results are shown in Figure $A-1$ and $T a b l e s$ $A-1, A-2, A-3$. 


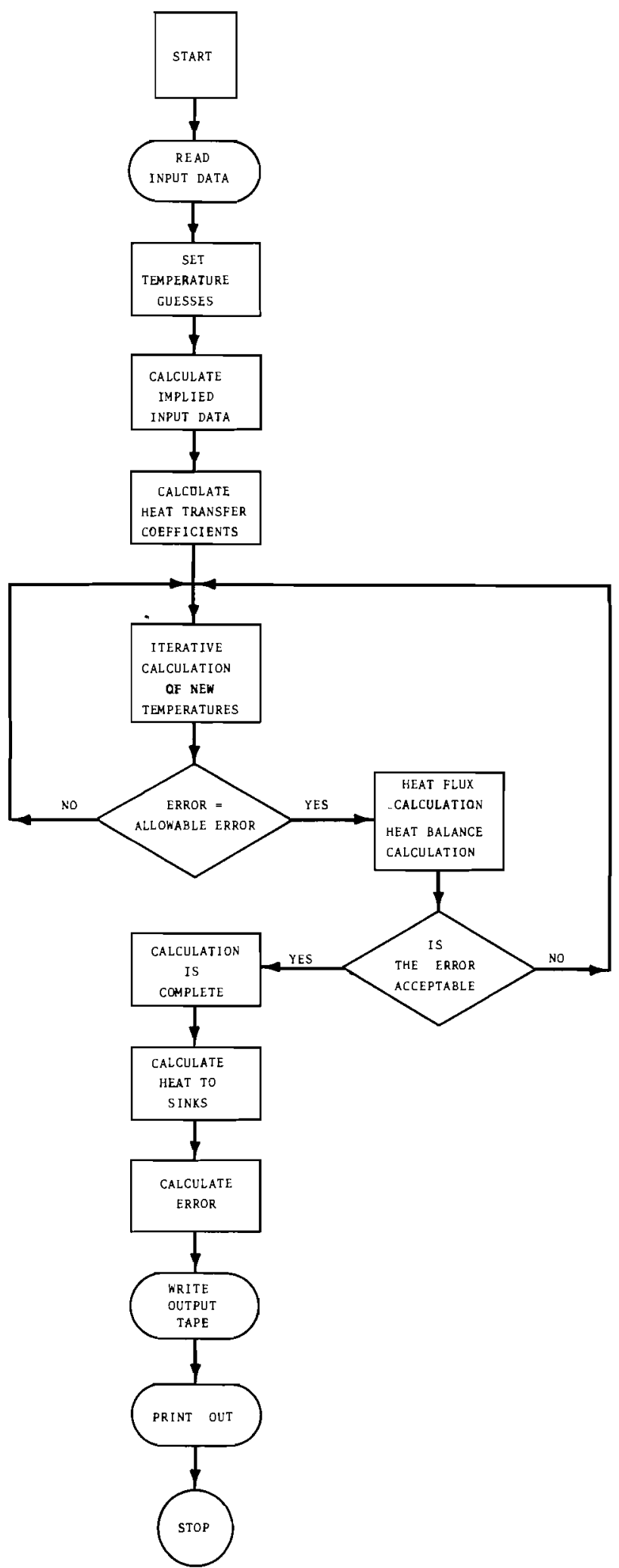

FIGURE A-1. Block Diagram of Heat Transfer Program 001 
TABLE A-1. Summary of Results of the Iterative calculations (Heat Generation Throughout the cake)

\begin{tabular}{|c|c|c|c|c|c|c|c|c|c|c|}
\hline Run No. & $\mathrm{k}_{\mathrm{s}}$ & ${ }^{k}{ }_{c}$ & $S$ & ${ }^{\ell} c$ & ${ }^{\ell} 1$ & $\mathrm{~T}_{\mathrm{MAX}}$ & $\mathrm{T}_{\text {WALL }}(\mathrm{a})$ & $\mathrm{T}_{2}$ & $\begin{array}{c}\frac{\mathrm{k}_{\mathrm{s}}\left(\mathrm{T}_{\mathrm{MAX}}-\mathrm{T}_{\mathrm{A}}\right)}{\mathrm{S}} \\
\mathrm{ft}^{2} \\
\end{array}$ & $\begin{array}{r}U_{U} / k_{s} \\
f^{-1} \\
\end{array}$ \\
\hline 105 & 0.15 & 0.33 & 2.00 & 4.0 & 11.0 & 482.4 & 456.9 & 480.8 & 30.9 & 0.1243 \\
\hline 110 & 0.15 & 0.33 & 2.83 & 4.0 & 11.0 & 651.6 & 615.2 & 649.2 & 30.8 & 0.1254 \\
\hline 111 & 0.15 & 0.80 & 2.83 & 4.0 & 11.0 & 618.2 & 603.1 & 617.4 & 29.0 & 0.1295 \\
\hline 103 & 0.15 & 0.80 & 2.00 & 4.0 & 11.0 & 457.0 & 446.4 & 456.4 & 29.0 & 0.1296 \\
\hline 104 & 0.15 & 1.20 & 2.83 & 4.0 & 11.0 & 610.8 & 600.3 & 610.3 & 28.7 & 0.1295 \\
\hline 109 & 0.15 & 1.20 & 2.00 & 4.0 & 11.0 & 452.8 & 445.3 & 452.4 & 28.7 & 0.1293 \\
\hline 1000 & 0.33 & 0.33 & 2.00 & 4.0 & 11.0 & 288.4 & 258.1 & 286.0 & 36.0 & 0.1185 \\
\hline 102 & 0.33 & 0.33 & 1.00 & 4.0 & 11.0 & 179.0 & 163.9 & 177.8 & 36.0 & 0.1188 \\
\hline 100 & 0.33 & 0.80 & 2.83 & 4.0 & 11.0 & 347.7 & 329.2 & 346.6 & 32.4 & 0.1198 \\
\hline 101 & 0.33 & 1.20 & 2.00 & 4.0 & 11.0 & 261.4 & 254.6 & 260.9 & 31.6 & 0.1197 \\
\hline 107 & 0.65 & 0.33 & 2.83 & 4.0 & 11.0 & 262.3 & 216.1 & 257.3 & 44.2 & 0.1066 \\
\hline 108 & 0.65 & 0.80 & 2.83 & 4.0 & 11.0 & 234.6 & 212.7 & 233.1 & 37.8 & 0.1067 \\
\hline 106 & 0.65 & 1.20 & 2.00 & 4.0 & 11.0 & 182.2 & 170.9 & 181.6 & 36.5 & 0.1060 \\
\hline 2000 & 0.15 & 0.33 & 1.00 & 8.0 & 11.0 & 505.6 & 468.2 & 503.6 & 65.3 & 0.1334 \\
\hline 203 & 0.15 & 0.33 & 1.42 & 8.0 & 11.0 & 688.0 & 635.0 & 685.2 & 65.3 & 0.1323 \\
\hline 200 & 0.15 & 0.80 & 1.42 & 8.0 & 11.0 & 625.9 & 606.4 & 625.0 & 58.7 & 0.1336 \\
\hline 204 & 0.15 & 0.80 & 1.00 & 8.0 & 11.0 & 463.3 & 449.5 & 462.7 & 59.0 & 0.1328 \\
\hline 201 & 0.15 & 1.20 & 1.42 & 8.0 & 11.0 & 611.4 & 598.8 & 610.9 & 57.2 & 0.1338 \\
\hline 202 & 0.33 & 0.33 & 1.00 & 8.0 & 11.0 & 309.8 & 267.8 & 306.8 & 79.1 & 0.1264 \\
\hline 205 & 0.33 & 0.33 & 1.42 & 8.0 & 11.0 & 409.8 & 350.6 & 405.6 & 78.9 & 0.1269 \\
\hline 207 & 0.33 & 1.20 & 1.42 & 8.0 & 11.0 & 339.7 & 325.0 & 339.0 & 62.6 & 0.1284 \\
\hline 211 & 0.65 & 0.33 & 1.00 & 8.0 & 11.0 & 221.6 & 179.5 & 217.1 & 98.5 & 0.1258 \\
\hline 210 & 0.65 & 0.80 & 1.42 & 8.0 & 11.0 & 241.0 & 215.4 & 239.4 & 78.2 & 0.1185 \\
\hline 208 & 0.65 & 1.20 & 1.42 & 8.0 & 11.0 & 228.5 & 211.6 & 227.6 & 72.5 & 0.1185 \\
\hline 209 & 0.65 & 1.20 & 0.283 & 8.0 & 11.0 & 101.9 & 98.48 & 101.7 & 73.3 & 0.1169 \\
\hline $213^{(b)}$ & 0.15 & 0.80 & 1.42 & 8.0 & 7.0 & 521.4 & 503.1 & 520.7 & 47.7 & 0.1724 \\
\hline $214^{(b)}$ & 0.15 & 1.20 & 1.00 & 8.0 & 7.0 & 376.7 & 368.4 & 376.4 & 46.0 & 0.1729 \\
\hline 302 & 0.15 & 0.33 & 0.498 & 16.0 & 11.0 & 561.6 & 501.8 & 558.9 & 147.5 & 0.1354 \\
\hline 303 & 0.15 & 0.33 & 0.142 & 16.0 & 11.0 & 210.7 & 193.7 & 209.9 & 148.6 & 0.1338 \\
\hline 309 & 0.15 & 0.80 & 0.707 & 16.0 & 11.0 & 663.1 & 631.8 & 662.1 & 125.9 & 0.1336 \\
\hline 308 & 0.25 & 1.20 & 0.707 & 16.0 & 11.0 & 636.8 & 617.0 & 636.2 & 120.3 & 0.1378 \\
\hline 3000 & 0.33 & 0.33 & 0.498 & 16.0 & 11.0 & 351.6 & 287.3 & 338.8 & 185.6 & 0.1530 \\
\hline 300 & 0.33 & 0.33 & 0.142 & 16.0 & 11.0 & 150.1 & 132.2 & 148.0 & 186.1 & 0.2537 \\
\hline 301 & 0.33 & 0.33 & 0.707 & 16.0 & 11.0 & 468.5 & 378.8 & 458.1 & 186.0 & 0.2537 \\
\hline 304 & 0.33 & 0.33 & 0.071 & 16.0 & 11.0 & 110.4 & 101.4 & 109.3 & 188.6 & 0.1405 \\
\hline 307 & 0.33 & 0.33 & 1.00 & 16.0 & 11.0 & 632.6 & 506.0 & 617.9 & 185.6 & 0.1456 \\
\hline 305 & 0.33 & 0.80 & 0.498 & 16.0 & 11.0 & 293.8 & 268.6 & 292.7 & 147.7 & 0.1298 \\
\hline 310 & 0.33 & 0.80 & 0.142 & 16.0 & 11.0 & 133.7 & 126.6 & 133.4 & 148.0 & 0.1294 \\
\hline 306 & 0.33 & 1.20 & 0.707 & 16.0 & 11.0 & 363.5 & 340.9 & 362.7 & 137.0 & 0.1287 \\
\hline
\end{tabular}


TABLE A-1. (Contd)

\begin{tabular}{|c|c|c|c|c|c|c|c|c|c|c|}
\hline Run No. & $\mathrm{k}_{\mathrm{s}}$ & $k_{c}$ & $S$ & ${ }^{\ell} \mathrm{C}$ & ${ }^{\ell} 1$ & $\mathrm{~T}_{\text {MAX }}$ & $T_{\text {WALL }}(\mathrm{a})$ & $\mathrm{T}_{2}$ & $\frac{\mathrm{k}_{\mathrm{S}}\left(\mathrm{T}_{\mathrm{MAX}}{ }^{-\mathrm{T}} \mathrm{A}\right)}{\mathrm{S}}$ & $\begin{array}{c}U_{U} / k_{s} \\
f^{-1} \\
\end{array}$ \\
\hline 313 & 0.65 & 0.33 & 0.707 & 16.0 & 11.0 & 329.2 & 240.0 & 309.3 & 238.3 & 0.2008 \\
\hline 314 & 0.65 & 0.80 & 0.498 & 16.0 & 11.0 & 208.9 & 182.2 & 206.4 & 180.6 & 0.1289 \\
\hline 311 & 0.65 & 1.20 & 0.142 & 16.0 & 11.0 & 102.5 & 97.67 & 102.2 & 148.8 & 0.1459 \\
\hline 312 & 0.65 & 1.20 & 0.707 & 16.0 & 11.0 & 247.2 & 222.3 & 245.7 & 162.9 & 0.1234 \\
\hline $315^{\text {(b) }}$ & 0.15 & 0.33 & 0.707 & 16.0 & 7.0 & 664.0 & 582.1 & 660.4 & 126.0 & 0.1791 \\
\hline $316^{(b)}$ & 0.15 & 0.80 & 0.498 & 16.0 & 7.0 & 416.0 & 394.9 & 415.3 & 104.2 & 0.1737 \\
\hline $317^{(b)}$ & 0.15 & 1.20 & 0.142 & 16.0 & 7.0 & 163.1 & 159.4 & 163.0 & 98.4 & 0.0711 \\
\hline 503 & 0.15 & 0.33 & 0.472 & 24.0 & 11.0 & 801.1 & 701.3 & 792.1 & 232.2 & 0.1565 \\
\hline 506 & 0.15 & 0.80 & 0.472 & 24.0 & 11.0 & 681.9 & 645.7 & 680.2 & 194.5 & 0.1403 \\
\hline 505 & 0.15 & 1.20 & 0.472 & 24.0 & 11.0 & 649.0 & 637.6 & 648.2 & 184.0 & 0.1382 \\
\hline 5000 & 0.33 & 0.33 & 0.472 & 24.0 & 11.0 & 493.4 & 387.0 & 471.2 & 295.3 & 0.2357 \\
\hline 507 & 0.33 & 0.33 & 1.00 & 24.0 & 11.0 & 966.1 & 740.8 & 921.3 & 295.7 & 0.2342 \\
\hline 500 & 0.33 & 0.80 & 0.472 & 24.0 & 11.0 & 400.8 & 359.4 & 397.3 & 231.3 & 0.1476 \\
\hline 501 & 0.33 & 1.20 & 0.472 & 24.0 & 11.0 & 373.6 & 347.4 & 371.9 & 212.3 & 0.1395 \\
\hline 502 & 0.33 & 1.20 & 0.094 & 24.0 & 11.0 & 131.2 & 126.0 & 130.9 & 214.9 & 0.1366 \\
\hline 508 & 0.65 & 0.33 & 0.472 & 24.0 & 11.0 & 351.7 & 243.4 & 313.3 & 387.9 & - \\
\hline 509 & 0.65 & 0.80 & 0.472 & 24.0 & 11.0 & 276.6 & 232.2 & 269.1 & 284.5 & 0.1774 \\
\hline 511 & 0.65 & 0.80 & 0.330 & 24.0 & 11.0 & 214.9 & 183.8 & 209.5 & 285.3 & 0.1763 \\
\hline 510 & 0.65 & 1.20 & 0.472 & 24.0 & 11.0 & 254.8 & 225.8 & 251.5 & 254.5 & 0.1481 \\
\hline $\int_{7}^{t e n}$ & is the & $\operatorname{tank}$ & $2 t$ & at & in & e same & rizontal & ane as & the maximum & ake \\
\hline
\end{tabular}


TABLE A-2. Summary of Results of the Iterative Calculations (Heat Generation in Horizontal Layers)

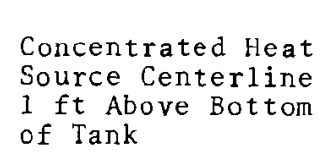

Concentrated Heat Source Centerline $7 \mathrm{ft}$ Above Tank Bottom

\begin{tabular}{|c|c|c|c|c|c|c|c|c|c|c|}
\hline Run No. & $\mathrm{k}_{\mathrm{s}}$ & $\mathrm{k}_{\mathrm{c}}$ & $\mathrm{k}_{\mathrm{g}}$ & $S$ & ${ }^{\ell_{C}}$ & ${ }^{\ell} \mathrm{g}$ & $\ell_{1}$ & $\mathrm{~T}_{\text {MAX }}$ & $T_{\text {WALL }}$ & 2 \\
\hline 321 & 0.15 & 0.33 & 0.33 & 5.67 & 16.0 & 2.0 & 11.0 & 953.7 & 814.6 & 947.8 \\
\hline 322 & 0.15 & 0.33 & 0.80 & 3.96 & 16.0 & 2.0 & 11.0 & 673.3 & 603.0 & 671.7 \\
\hline 323 & 0.15 & 0.33 & 1.20 & 1.13 & 16.0 & 2.0 & 11.0 & 242.0 & 224.8 & 241.7 \\
\hline 318 & 0.33 & 0.33 & 0.33 & 5.67 & 16.0 & 2.0 & 11.0 & 623.1 & 467.4 & 612.9 \\
\hline 319 & 0.33 & 0.33 & 0.80 & 1.13 & 16.0 & 2.0 & 11.0 & 170.2 & 147.1 & 169.4 \\
\hline 320 & 0.33 & 0.33 & 1.20 & 3.96 & 16.0 & 2.0 & 11.0 & 438.7 & 367.5 & 436.9 \\
\hline 330 & 0.15 & 0.33 & 0.33 & 5.67 & 16.0 & 2.0 & 11.0 & 820.3 & 723.7 & 787.7 \\
\hline 331 & 0.15 & 0.33 & 0.80 & 3.96 & 16.0 & 2.0 & 11.0 & 582.3 & 534.3 & 562.6 \\
\hline 332 & 0.15 & 0.33 & 1.20 & 1.13 & 16.0 & 2.0 & 11.0 & 216.7 & 204.9 & 211.3 \\
\hline
\end{tabular}


TABLE A-3. IBM 7090 Computer output for Iterative Calculations

[Total heat generation rate. 35,306 Btu/hr; Soil thermal conductivity, $0.15 B t u /(h r)\left(f t^{2}\right)\left({ }^{\circ} F / f t\right)$;

CALCULATIINN OF HEAT GENERATING TEMPERATURE NODEQ

PROGRAM O1R

MAX TEMP S.616E Q2 DEG F AT NODE 101

3.015E OA GTUTHR TO SINK 1 5.160E O3 BTUIAR TO SINK

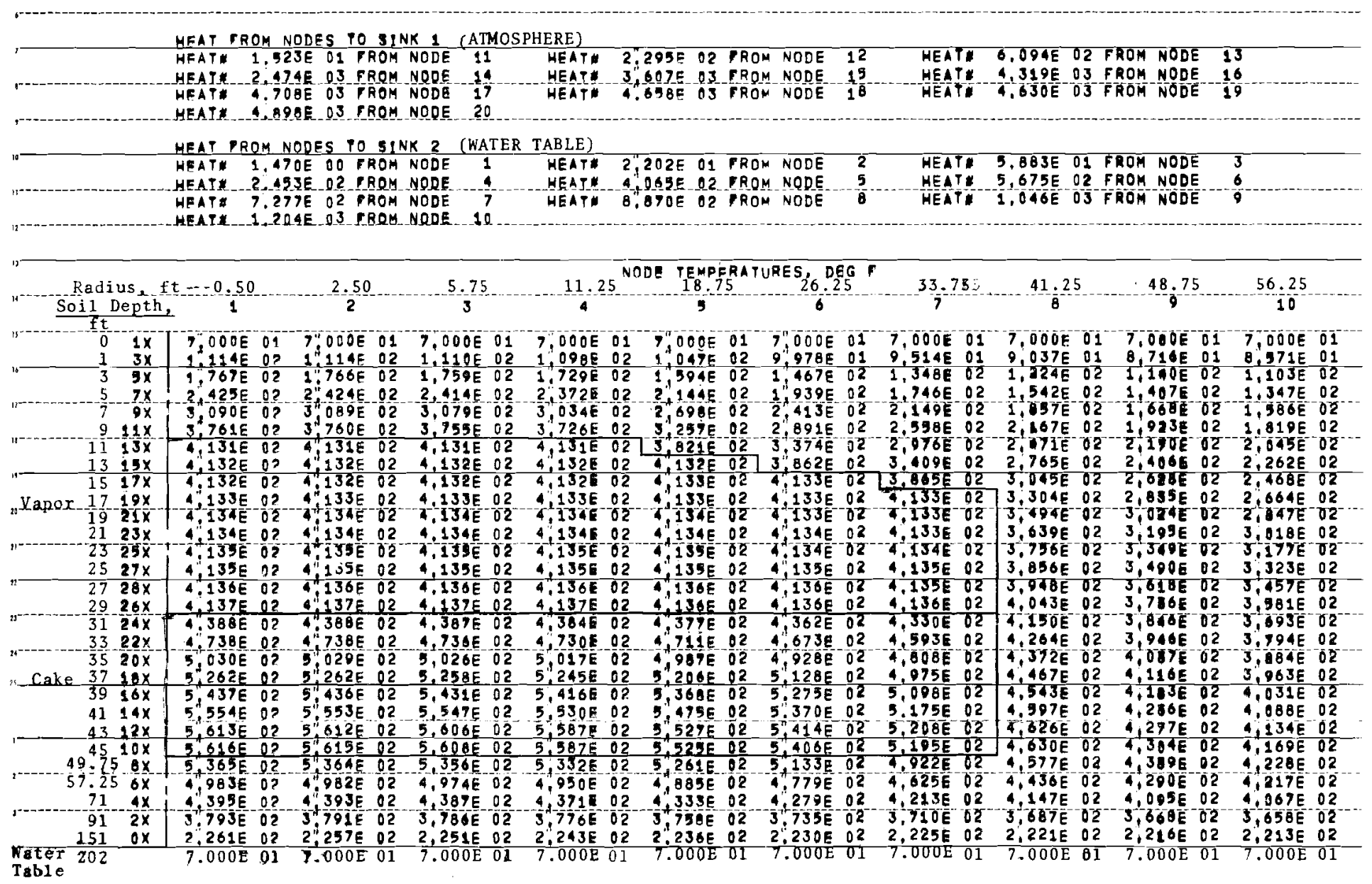


BNWL -262

APPENDIX B

DERIVATION OF EQUATIONS

FOR THE APPROXIMATE MODEL 


\section{APPENDIX B \\ DERIVATION OF EQUATIONS FOR THE APPROXIMATE MODEL}

Since the iterative technique has proved to be difficult to adjust for changes in soil geometry and has consumed large amounts of computer time because of its complexity, an approximate model has been developed to permit easier interpolation and variation of less important parameters. A sketch of the model is shown in Figure 11. A horizontal plane of maximum temperature across which no heat flows can be drawn through the heat-generating cake. All the heat is assumed to flow vertically through the cake so that a parabolic vertical temperature profile is present. This is a good assumption only near the axis of the tank because radial heat losses will reduce the temperature near the walls.

The total heat generated in the cake is conducted to the water table and the atmosphere with effective overall heat transfer coefficients as is shown in Equations (B-1) and (B-2).

$$
\begin{aligned}
& S \pi r^{2} \ell_{C}=\pi r^{2} U_{D}\left(T_{2}-T_{W}\right)+\pi r^{2} U_{U}\left(T_{1}-T_{A}\right) \\
& S \pi r^{2} X_{N}=\pi r^{2} U_{D}\left(T_{2}-T_{W}\right)
\end{aligned}
$$

The relationship between the temperature $\mathrm{T}_{1}$ at the top of the cake and $\mathrm{T}_{2}$ at the bottom of the cake is found by equating the null plane temperatures calculated from both sides;

$$
\mathrm{T}_{\text {MAX }}=\mathrm{T}_{2}+\frac{\mathrm{SX}_{\mathrm{N}}^{2}}{2 \mathrm{k}_{\mathrm{c}}}=\mathrm{T}_{1}+\frac{\mathrm{s}\left(\mathrm{e}_{\mathrm{c}}-\mathrm{x}_{\mathrm{N}}\right)^{2}}{2 \mathrm{k}_{\mathrm{c}}}
$$

Solving Equations $(B-1),(B-2)$, and $(B-3)$ simultaneously for $\mathrm{X}_{N}, \mathrm{~T}_{1}$ and $\mathrm{T}_{2}$ gives

$$
\mathrm{X}_{\mathrm{N}}=\frac{\mathrm{U}_{\mathrm{D}}}{\mathrm{S}}\left(\mathrm{T}_{2}-\mathrm{T}_{\mathrm{W}}\right) \text {, }
$$




$$
\mathrm{T}_{1}=\mathrm{T}_{2}\left(1+\frac{\mathrm{U}_{\mathrm{D}^{\ell} \mathrm{c}}}{\mathrm{k}_{\mathrm{c}}}\right)-\frac{\mathrm{Sl}_{\mathrm{c}}{ }^{2}}{2 \mathrm{k}_{\mathrm{c}}}-\frac{{ }_{\mathrm{c}}{ }_{\mathrm{c}} \mathrm{U}_{\mathrm{D}} \mathrm{T}_{W}}{\mathrm{k}_{\mathrm{c}}}
$$

and

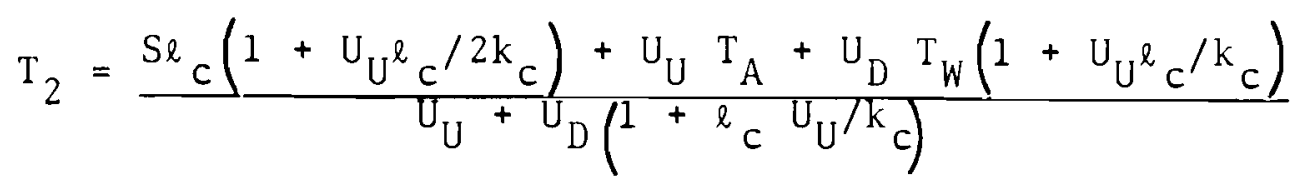

When the sink temperatures are equal $\mathrm{T}_{\mathrm{A}}=\mathrm{T}_{W}$,

$\int \mathrm{T}_{2}-\mathrm{T}_{\mathrm{A}}=\frac{\mathrm{Sl}_{\mathrm{c}}\left(1+\mathrm{U}_{\mathrm{U}^{\ell} \mathrm{c}} / 2 \mathrm{k}_{\mathrm{c}}\right)}{\mathrm{U}_{\mathrm{U}}+\mathrm{U}_{\mathrm{D}}\left(1+\mathrm{e}_{\mathrm{c}} \mathrm{U}_{\mathrm{U}} / \mathrm{k}_{\mathrm{c}}\right)}$

The evaluation of $U_{U}$ and $U_{D}$ is based upon the heat flow paths shown in Figure 11. The average areas for flow and the driving forces are given in Table B-1. The flux to the water table may be split up into two parallel flows so that

$$
\mathrm{U}_{\mathrm{D}}=\mathrm{U}_{\mathrm{Q}_{3}}+\mathrm{U}_{\mathrm{D}}
$$

The heat transfer coefficient for flow out the bottom of the cake is then

$$
\mathrm{U}_{\mathrm{Q}_{\mathrm{D}}}=\frac{\mathrm{k}_{\mathrm{s}}}{\ell_{3}}
$$

and out the side of the cake is

$$
\mathrm{U}_{\mathrm{Q}_{3}}=\frac{\mathrm{k}_{\mathrm{S}}\left(\frac{\mathrm{R}^{2}}{\mathrm{r}^{2}}-1\right)}{\mathrm{l}_{3}+\mathrm{R} / 2}
$$

The flux to the atmosphere may be split up into three paths so that

$$
\mathrm{U}_{\mathrm{U}}=\mathrm{U}_{\mathrm{Q}_{\mathrm{U}}}+\mathrm{U}_{\mathrm{Q}_{1}}+\mathrm{U}_{\mathrm{Q}_{2}}
$$


TABLE B-1. Heat Flow Assumptions in Approximate Model

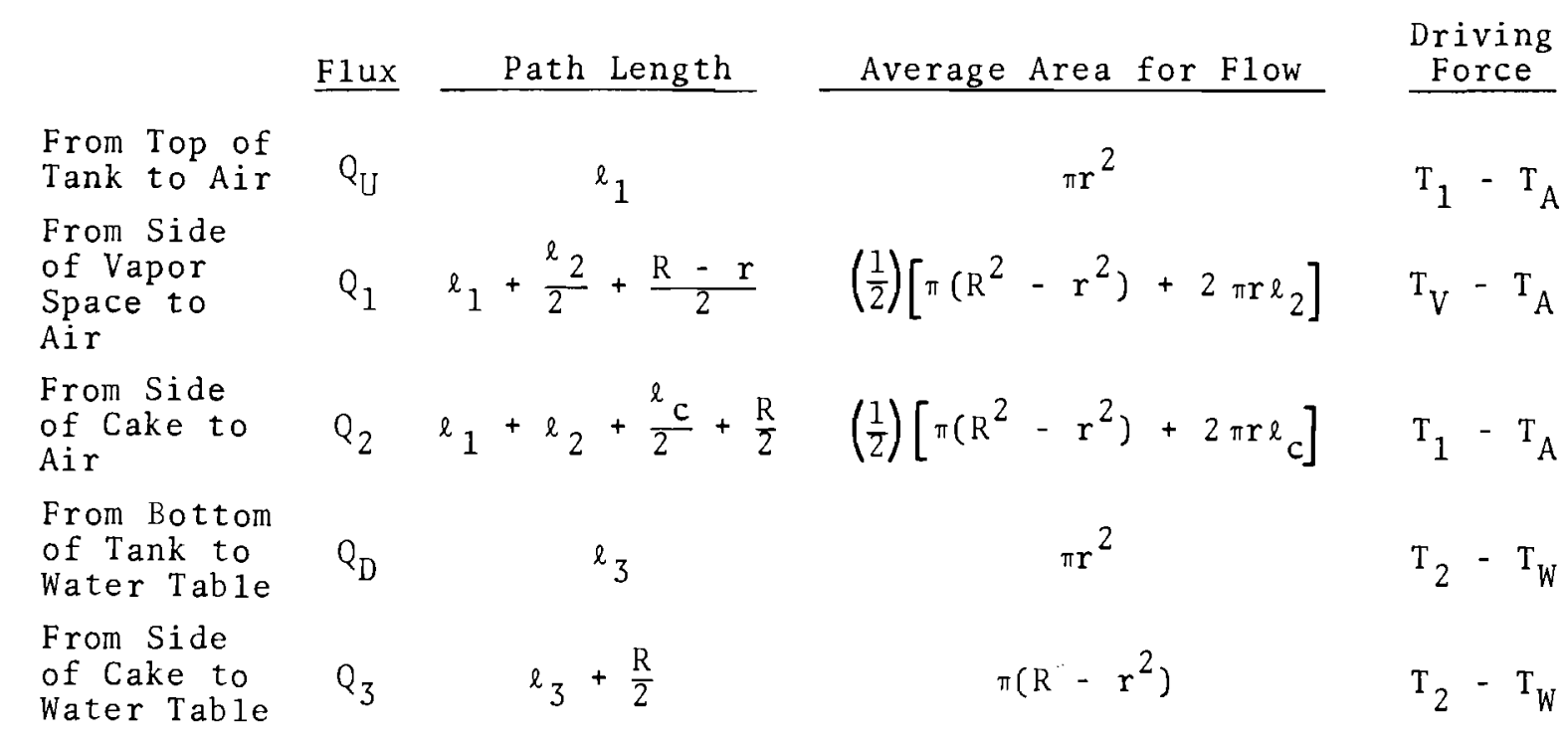

The heat that flows out the side of the cake is assumed to leave the cake at temperature $\mathrm{T}_{1}$ so that

$$
\mathrm{U}_{\mathrm{Q}_{2}}=\frac{\frac{1}{2} \mathrm{k}_{\mathrm{s}}\left(\frac{\mathrm{R}^{2}}{\mathrm{r}^{2}}-1+\frac{2{ } \mathrm{c}}{\mathrm{r}}\right)}{\ell_{1}+\ell_{2}+\frac{{ }^{{ }_{C}}}{2}+\frac{\mathrm{R}}{2}} \text {. }
$$

The heat transfer coefficient for flow vertically through the vapor space and the soil cover above the tank is found by adding the series resistances to flow.

$$
\mathrm{U}_{\mathrm{Q}_{U}}=\frac{1}{\frac{1}{\mathrm{~h}_{1}}+\frac{\ell_{2}}{\mathrm{k}_{\mathrm{v}}}+\frac{1}{\mathrm{~h}_{2}}+\frac{l_{1}}{\mathrm{k}_{\mathrm{s}}}+\frac{1}{\mathrm{~h}_{\mathrm{A}}}} \text {. }
$$

The effect of the heat that flows out the side of the vapor space on the vertical temperature gradient is neglected in the calculation of $\mathrm{U}_{\mathrm{QU}}$. The effects of the vertical heat flow and the cake to vapor heat transfer coefficient are neglected in the calculation of the heat transfer coefficient for flow from the side of the vapor space to the atmosphere. 


$$
\mathrm{U}_{\mathrm{Q}_{1}}=\frac{1}{\frac{2 \ell_{2}}{\mathrm{~h}_{\mathrm{Q}_{1} \mathrm{r}}}+\frac{\ell_{1}+\ell_{2}+\frac{\mathrm{R}-\mathrm{r}}{2}}{\frac{1}{2} \mathrm{k}_{\mathrm{s}}\left(\frac{\mathrm{R}^{2}}{\mathrm{r}^{2}}-1+\frac{2 \ell_{2}}{\mathrm{r}}\right)}+\frac{1}{\mathrm{~h}_{\mathrm{A}}\left(\frac{\mathrm{R}^{2}}{\mathrm{r}^{2}}-1\right)}}
$$

The side of vapor space-to-soil, conduction through soil, and soil-to-air heat transfer coefficients are treated as series resistances to flow.

The temperature of the vapor space can be estimated from

$$
T_{V}=T_{1}-\frac{S\left(\ell_{c}-X_{N}\right)}{h_{1}}\left(1-\frac{U_{Q_{2}}}{U_{U}}\right)
$$

When the heat-generating fission products are concentrated in a layer within the cake, the internal structure of the cake must be taken into account. If $\ell_{g}$ is the heat-generating layer thickness with thermal conductivity $\mathrm{k}_{\mathrm{g}}$, $\ell_{\mathrm{d}}$ is the thickness of the nongenerating layer of the cake below the heat generators with thermal conductivity $k_{d}$, and $\ell_{c}-\ell_{g}-\ell_{d}$ is the thickness of the nongenerating 1 ayer above the heat generators with thermal conductivity $k_{t}$, the overall heat transfer coefficients $U_{U}$ and $U_{D}$ and $T_{2}$ and $T_{1}$ may be redefined to refer to the heatgenerating layer. The temperature at the bottom of the heatgenerating 1 ayer is then

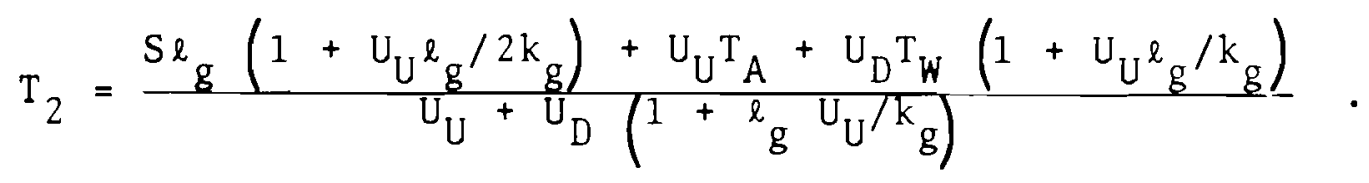

The expressions for $U_{U}$ and $U_{D}$ are then

$$
U_{U}=\frac{1}{\frac{{ }_{c}-l_{g}-{ }^{\ell} d}{k_{t}}+\frac{1}{U_{Q_{U}}+U_{Q_{1}}+U_{Q_{2}}}}
$$


and

$$
\mathrm{U}_{\mathrm{D}}=\frac{1}{\frac{\mathrm{d}}{\mathrm{k}_{\mathrm{d}}}+\frac{1}{\mathrm{U}_{\mathrm{Q}_{\mathrm{D}}}+\mathrm{U}_{\mathrm{Q}_{3}}}}
$$

\section{POINT SOURCE APPROXIMATION}

The equation for the temperature field around a continuous point source in an infinite medium of soil is

$$
\mathrm{T}=\frac{\mathrm{Q}}{4 \pi \mathrm{k}_{\mathrm{s}} \mathrm{y}}
$$

where $Q$ is the total heat generated in Btu/hr and $y$ is the distance from the source to the point of temperature measurement. If a plane surface at atmospheric temperature $\mathrm{T}_{A}$ is introduced at distance $D$ from the source and the point in question is distance $x$ from the plane and distance $r$ from the normal to the plane through the source, the temperature field found by using a negative reflection of the source across the plane is:

$$
\begin{aligned}
T(r, x)-T_{A}= & \frac{Q}{4 \pi k s}\left\{\left[r^{2}+(D-x)^{2}\right]^{-1 / 2}\right. \\
& \left.-\left[r^{2}+(D+x)^{2}\right]^{-1 / 2}\right\} .
\end{aligned}
$$

The introduction of a plane surface water table with temperature $\mathrm{T}_{\mathrm{A}}$ at depth $\mathrm{w}$ in the soil may be accommodated by multiple reflections of the source about the planes to give

$$
\begin{aligned}
\stackrel{4 \pi k}{S} \frac{\left[T(r, x)-T_{A}\right]=}{Q} & {\left[r^{2}+(D-x)^{2}\right]^{-1 / 2}-\left[r^{2}+(D+x)^{2}\right]^{-1 / 2} } \\
& +\sum_{n=2}^{\infty}\left\{\left[r^{2}+(n w-D-x)^{2}\right]^{-1 / 2}\right. \\
& +\left[r^{2}+(n w-D+x)^{2}\right]^{-1 / 2} \\
& +\left[r^{2}+(n w-D-x)^{2}\right]^{-1 / 2} \\
& \left.+\left[r^{2}+(n w+D+x)^{2}\right]^{-1 / 2}\right\}
\end{aligned}
$$


The heat flow across a given radius $R$ is found by differentiating Equation $(B-21)$ to give

$$
Q_{R}=-k_{S}(2 \pi R) \int_{0}^{W}\left[\frac{d T(r, x)}{d r}\right]_{r=R} d x
$$

For a first approximation it may be assumed that the fraction, $f$, of heat going to the atmosphere is independent of the outer radius of the system as was shown in the analysis of Figure 18 . Then

$$
Q_{R}=\frac{-k_{s}(2 \pi R)}{f} \int_{0}^{D}\left[\frac{d T(r, x)}{d r}\right]_{r=R} d x
$$

Since the region of the integration is far removed from the water table, Equation $(B-20)$ is sufficient to express the temperature and substitution into Equation (B-23) gives

$$
\begin{gathered}
\left.\frac{d T}{d x}\right|_{r=R}=\frac{-Q_{R}}{4 \pi k_{S}}\left\{\left[R^{2}+(D-x)^{2}\right]^{-3 / 2}-\left[R^{2}+(D+x)^{2}\right]^{-3 / 2}\right\} \\
\frac{f Q_{R}}{Q}=[1+(R-24) \\
\left.\frac{(B / D)^{2}}{Q}\right]^{-1 / 2}-\left[4+(R / D)^{2}\right]^{-1 / 2} .
\end{gathered}
$$

Using $R=60 \mathrm{ft}$ and $D=47 \mathrm{ft}$ gives a value of $\mathrm{fQ}_{\mathrm{R}} / \mathrm{Q}$, the fraction of heat going to the atmosphere outside the $60 \mathrm{ft}$ radius for a solitary tank, which is $27.0 \%$, somewhat lower than the value of $31 \%$ given in the analysis of Figure 19 . Reducing $D$ to $35 \mathrm{ft}$ to allow for the high thermal conductivity of the vapor space matches the iterative results at large distances from the tank.

In another application of the point source approximation, all the space between the bottom of the tank and the atmosphere was shrunk by $35 / 47$ and the first set $(n=2)$ of terms of the summation in Equation $(B-21)$ was used throughout the region 
outside the $60 \mathrm{ft}$ radius between the water table and the atmosphere to obtain an initial guess for the iterative technique. This appears to work we 11 in decreasing the time to convergence of the iterative technique.

For tank spacings greater than $120 \mathrm{ft}$, an insulated radius $R_{1}$ of half the tank spacing can be assumed for the calculation of the heat transferred across $R=60 \mathrm{ft}$

$$
\begin{aligned}
Q_{R}= & \frac{1}{f}\left\{\left[1+(R / D)^{2}\right]^{-1 / 2}-\left[4+(R / D)^{2}\right]^{-1 / 2}\right. \\
& \left.-\left[1+\left(R_{1} / D\right)^{2}\right]^{-1 / 2}+\left[4+\left(R_{1} / D\right)^{2}\right]^{-1 / 2}\right\}
\end{aligned}
$$

and the heat generated within the cake can be reduced to $Q-Q_{R}$ for calculation within the $60 \mathrm{ft}$ radius. This will give a cake temperature which is somewhat too low because the influence of the radial heat flow upon temperature gradients within the $60 \mathrm{ft}$ system is not considered. Such a correction is made in the point source correction to the approximate model in Figure 16. 

BNWL -262

\author{
APPENDIX C \\ UTTA \\ COMPUTER PROGRAM FOR CALCULATIONS \\ USING THE APPROXIMATE MODEL
}




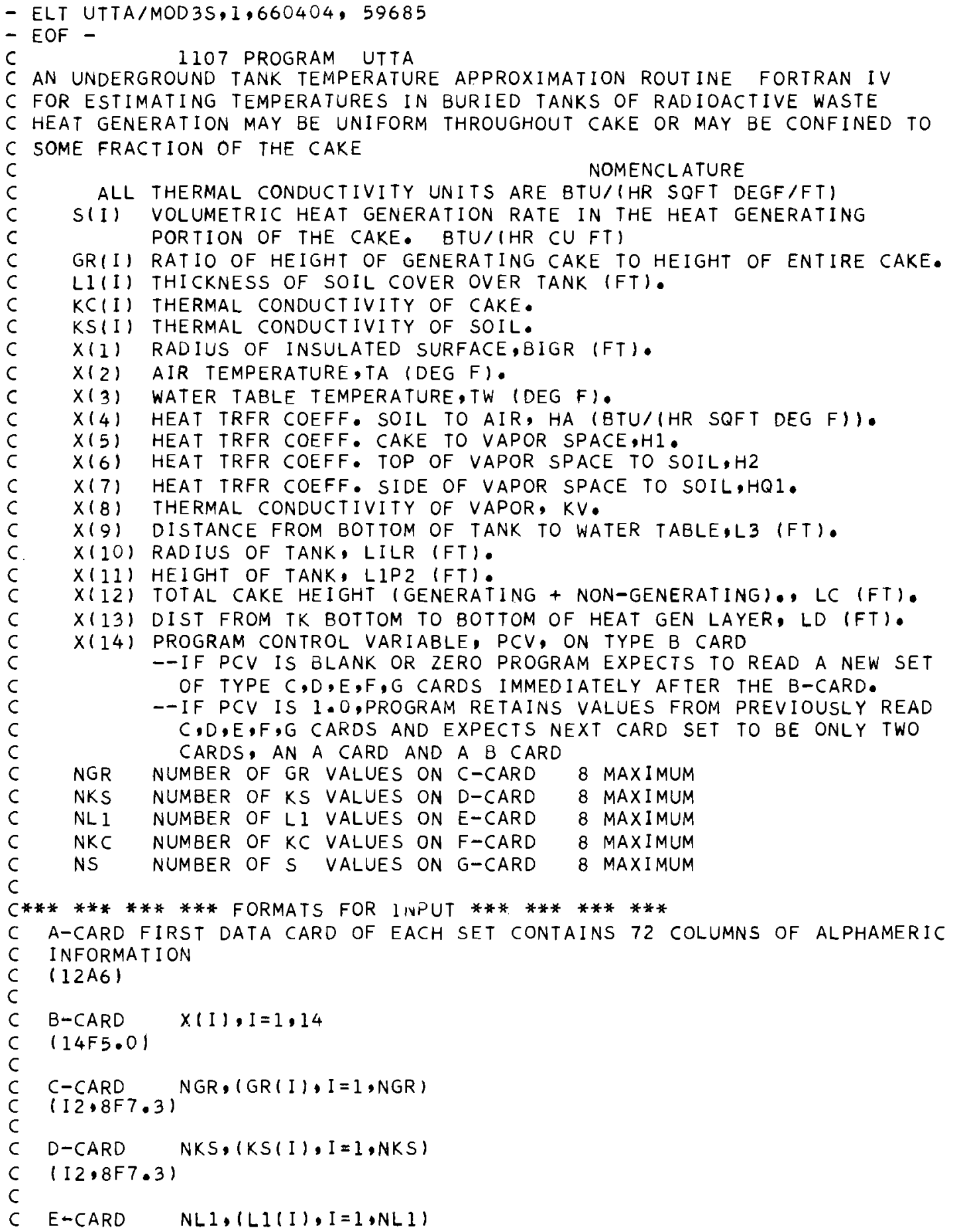




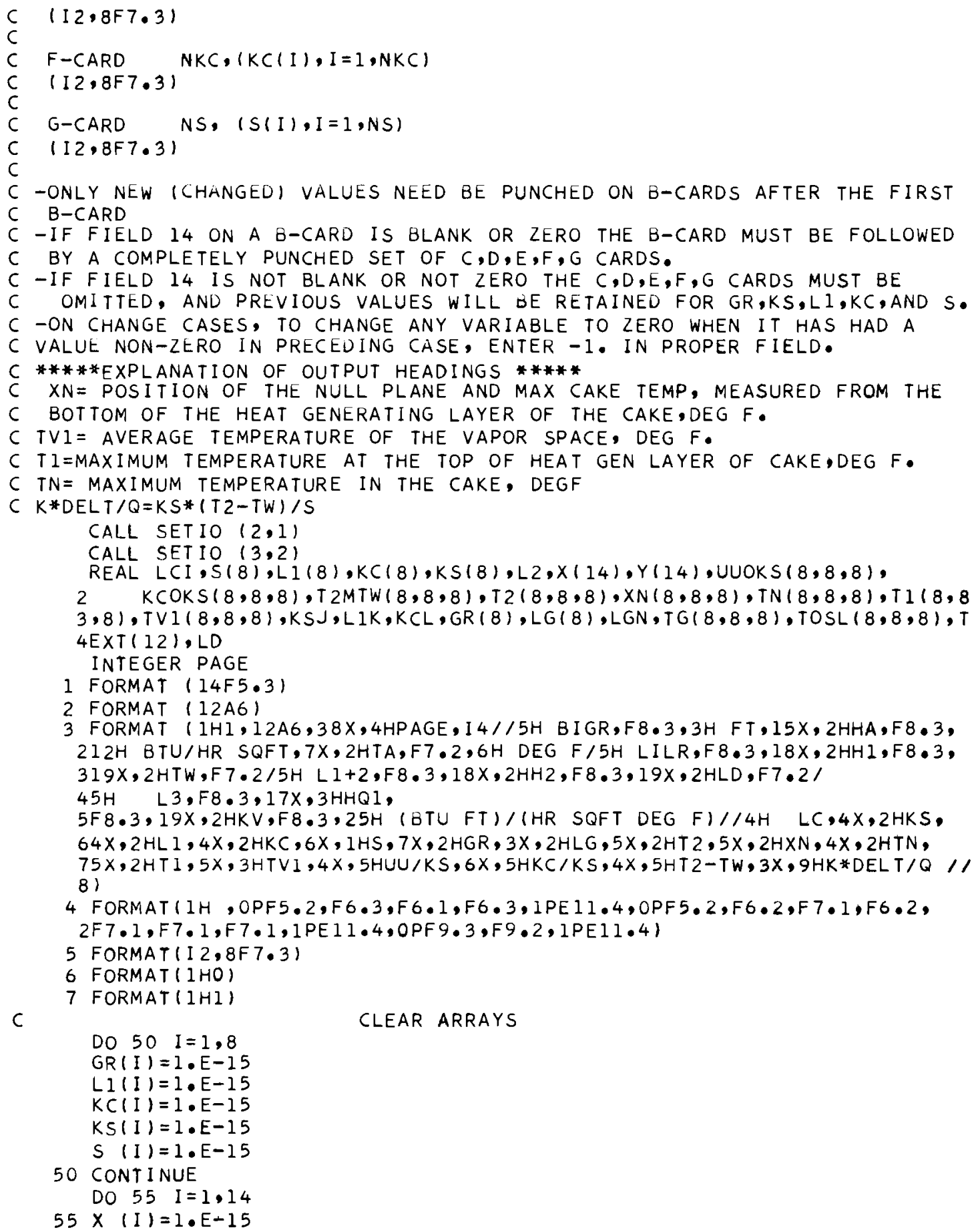




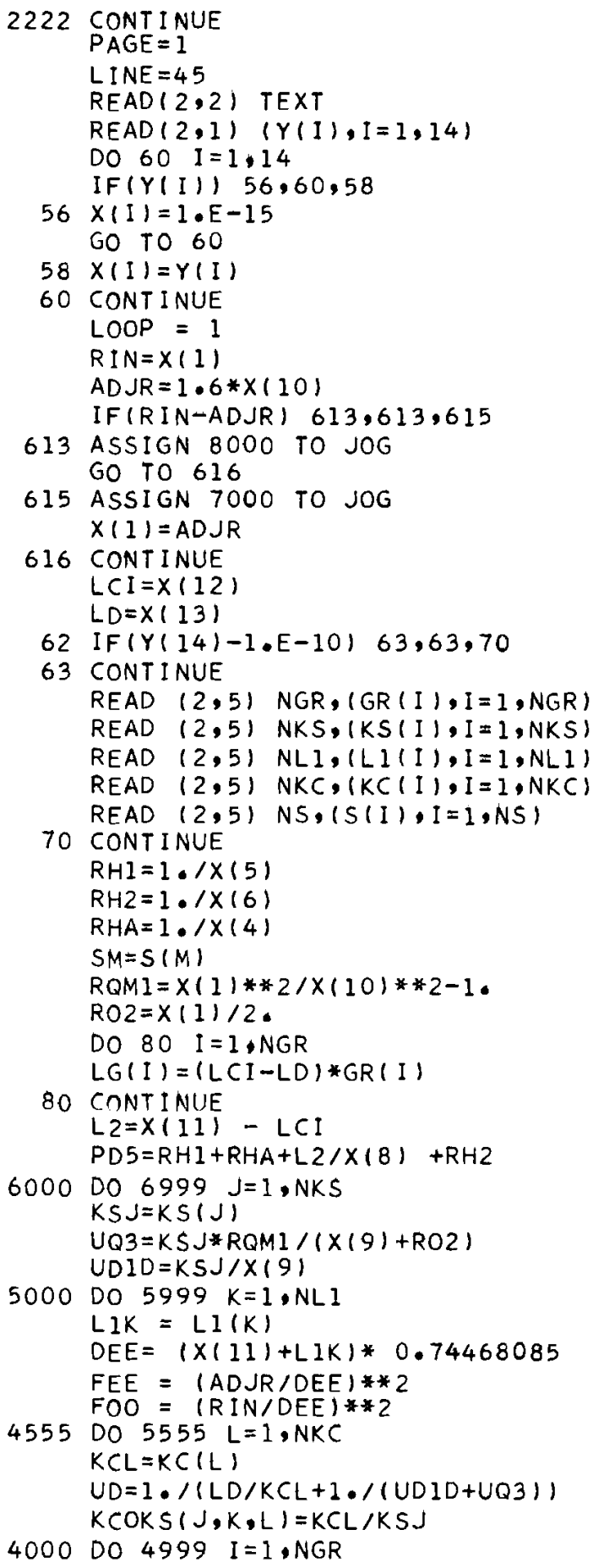




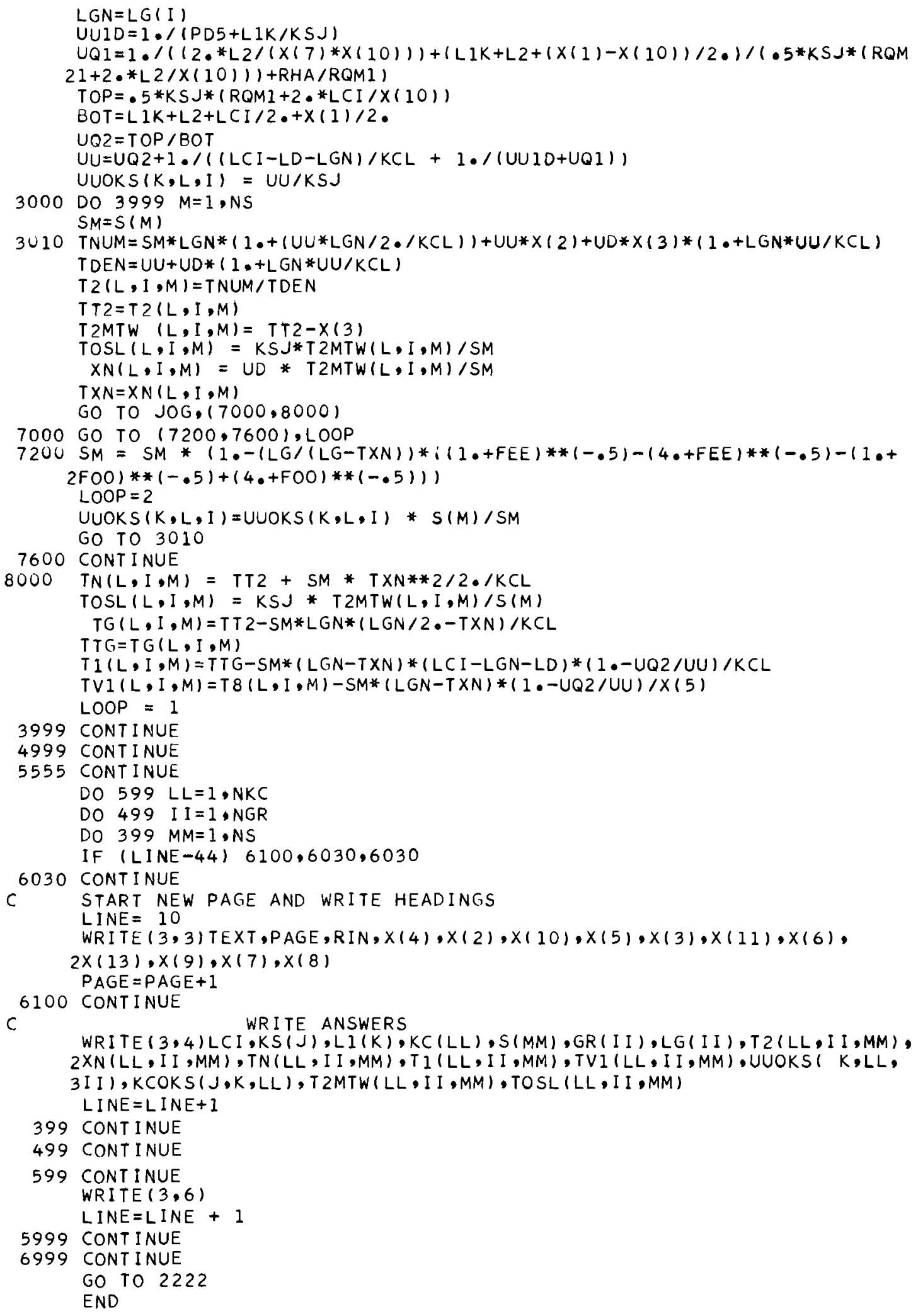




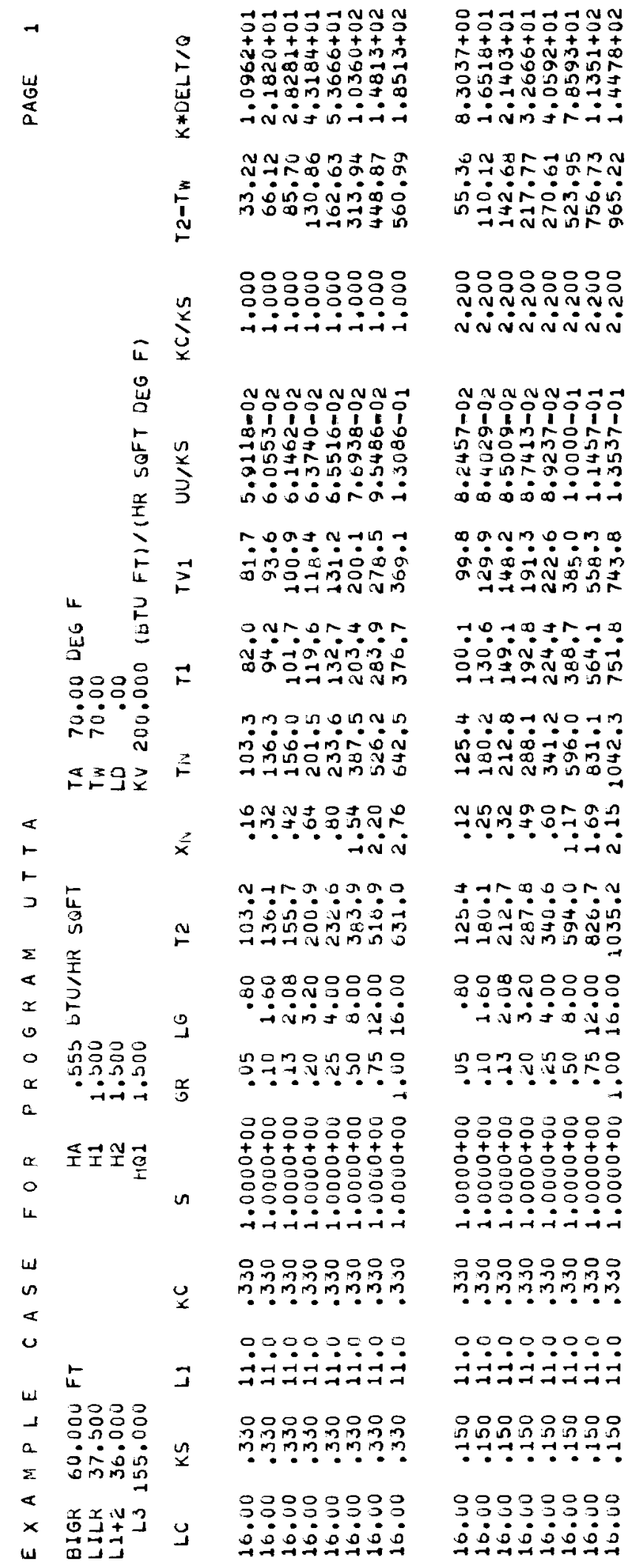




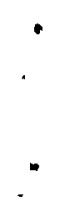


BNWL - 262

\section{APPENDIX D}

EXAMPLE PROBLEMS 


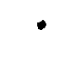




\section{APPENDIX D}

\section{EXAMPLE PROBLEMS}

\section{EXAMPLE 1. CALCULATION OF THE MAXIMUM TEMPERATURE FOR A TYPICAL HANFORD TANK}

- Data: $k_{c}=0.33, k_{s}=0.15, \ell_{1}=11 \mathrm{ft}, \ell_{2}+\ell_{c}=36 \mathrm{ft}$, $\ell_{c}=16 \mathrm{ft}, k_{m}=0.5, \ell_{3}=155 \mathrm{ft}, R=60 \mathrm{ft}$, $r=37.5 \mathrm{ft}, \mathrm{T}_{\mathrm{A}}=\mathrm{T}_{\mathrm{W}}=70^{\circ} \mathrm{F}$

Total heat generation rate $Q$ is $40,000 \mathrm{Btu} / \mathrm{hr}$.

- What are the maximum temperatures at the bottom of the tank and in the cake?

Ratio of thermal conductivities: $k_{c} / k_{s}=0.33 / 0.15=2.2$. From Figure 12, $\mathrm{k}_{\mathrm{S}}\left(\mathrm{T}_{2}-\mathrm{T}_{\mathrm{A}}\right) / \mathrm{S}=150 \mathrm{ft}^{2}$.

$\left.\begin{array}{l}\text { Volumetric heat } \\ \text { generation rate }\end{array}\right\}=\frac{Q}{\pi r^{2} \ell_{c}}=\frac{40,000}{(\pi)(37.5)^{2}(16)}=0.564 \mathrm{Btu} /(\mathrm{hr})\left(\mathrm{ft}^{3}\right)$.

Maximum temperature at the bottom of the cake:

$$
\mathrm{T}_{2}=70+\frac{(150)(0.564)}{0.15}=636^{\circ} \mathrm{F} \text {. }
$$

Overall cake-to-water table heat transfer coefficient from Equation $(B-8)$ :

$$
\begin{aligned}
U_{D} & =\frac{k_{s}}{\ell_{3}}+\frac{k_{s}\left(R^{2} / r^{2}\right)-1}{\ell_{3}+R / 2}=\frac{0.15}{155}+\frac{(0.15)\left(\frac{60^{2}}{37.5^{2}}-1\right)}{155+60 / 2} \\
& =0.002233 \mathrm{Btu} /(\mathrm{hr})\left(\mathrm{ft} \mathrm{f}^{2}\right)\left({ }^{\circ} \mathrm{F}\right) .
\end{aligned}
$$

Position of maximum cake temperature, Equation (B-4):

$$
X_{N}=\frac{U_{D}}{S}\left(T_{2}-T_{W}\right)=\frac{(0.002233)(636-70)}{0.564}=2.23 \mathrm{ft} \text {. }
$$


Maximum temperature in the cake, Equation $(B-3)$ :

$$
\mathrm{T}_{\text {MAX }}=\mathrm{T}_{2}+\frac{\mathrm{SX}_{\mathrm{N}}^{2}}{2 \mathrm{k}_{\mathrm{C}}}=636+\frac{(0.564)(2.23)^{2}}{(2)(0.33)}=640^{\circ} \mathrm{F}
$$

This maximum temperature could have been gotten directly from Figure 9, or from the maximum cake temperature group given in Figure 10 .

Maximum steady-state temperature gradient across the concrete (below the cake) from Table II:

$$
\frac{d T}{d X}=\frac{S X_{N}}{k_{m}}=\frac{(0.564)(2.23)}{0.5}=2.5^{\circ} \mathrm{F} / \mathrm{ft} \text {. }
$$

Maximum temperature at the top of the cake, Equation (B-3):

$$
\begin{aligned}
T_{1} & =T_{\text {MAX }}-\frac{s\left(\ell_{c}-x_{N}\right)^{2}}{2 k_{C}} \\
& =640-\frac{(0.564)(16-2.23)^{2}}{2(0.33)}=477^{\circ} \mathrm{F} .
\end{aligned}
$$

Temperature of the vapor space, Equation (B-15):

$$
T_{V}=T_{1}-\frac{S\left(\ell_{c}-x_{N}\right)}{h_{1}}=477-\frac{(0.564)(13.77)}{1.5}=472^{\circ} \mathrm{F}
$$

\section{EXAMPLE 2. REMOVAL OF SOIL COVER}

- Data: Same as Example 1, except the soil cover depth $\ell_{1}$ is $7 \mathrm{ft}$ instead of $11 \mathrm{ft}$.

- What is the maximum temperature at the bottom of the cake?

From Figure 15,

$$
\begin{gathered}
\frac{\mathrm{k}_{\mathrm{S}}\left(\mathrm{T}_{2}-\mathrm{T}_{\mathrm{A}}\right)}{\mathrm{S}}=125 \mathrm{ft}^{2} \\
\mathrm{~T}_{2}=70+\frac{(125)(0.564)}{0.15}=542^{\circ} \mathrm{F} .
\end{gathered}
$$




\section{EXAMPLE 3. ESTIMATION OF MAXIMUM TEMPERATURES \\ FROM SYSTEM PROPERTIES}

- Data: $k_{c}=1.0, k_{s}=0.25, \ell_{1}=5 \mathrm{ft}, \ell_{2}+\ell_{c}=30 \mathrm{ft}$,

$$
\begin{aligned}
& \ell_{c}=10 \mathrm{ft}, \mathrm{k}_{\mathrm{v}}=100, \ell_{3}=120 \mathrm{ft}, \mathrm{R}=55 \mathrm{ft}, \\
& \mathrm{r}=30 \mathrm{ft}, \mathrm{T}_{\mathrm{A}}=35^{\circ} \mathrm{F}, \mathrm{T}_{\mathrm{W}}=100^{\circ} \mathrm{F}, \mathrm{h}_{\mathrm{Q}_{1}}=1, \mathrm{~h}_{\mathrm{A}}=1, \\
& \mathrm{~h}_{1}=1 \mathrm{~h}_{2}=1, \mathrm{~S}=2 \mathrm{Btu} /(\mathrm{hr})\left(\mathrm{ft}^{3}\right)
\end{aligned}
$$

- What is the maximum temperature at the bottom of the tank?

Since the values of the parameters in this problem are different from those presented in the graphical correlations, the heat transfer coefficients must be calculated by the equations in Appendix B.

Cake-to-water table heat transfer coefficient, Equation $(\mathrm{B}-8):$

$$
\begin{aligned}
U_{D} & =\frac{k_{s}}{\ell_{3}}+\frac{k_{s}\left(R^{2} / r^{2}-1\right)}{\ell_{3}+R / 2}=\frac{0.25}{120}+\frac{0.25\left[\left(\frac{55}{30}\right)^{2}-1\right]}{120+55 / 2} \\
& =0.00608 \mathrm{Btu} /(\mathrm{hr})\left(\mathrm{ft}^{2}\right)\left({ }^{\circ} \mathrm{F}\right) .
\end{aligned}
$$

Cake-to-atmosphere heat transfer coefficient, Equation $(\mathrm{B}-11)$ :

$$
\begin{aligned}
& U_{U}=\frac{\frac{1}{2} k_{s}\left(\frac{R^{2}}{r^{2}}-1+\frac{2 \ell_{c}}{r}\right)}{\ell_{1}+\ell_{2}+\frac{\ell_{c}}{2}+\frac{R}{2}}+\frac{1}{\frac{1}{h_{1}}+\frac{\ell_{2}}{k_{v}}+\frac{1}{h_{2}}+\frac{\ell_{1}}{k_{s}}+\frac{1}{h_{A}}} \\
& +\frac{\frac{1}{2 \ell_{2}}}{\mathrm{~h}_{\mathrm{Q}_{1} \mathrm{r}}+\frac{\ell_{1}+\ell_{2}+\frac{\mathrm{R}-\mathrm{r}}{2}}{\frac{1}{2} \mathrm{k}_{\mathrm{s}}\left(\frac{\mathrm{R}^{2}}{\mathrm{r}^{2}}-1+\frac{2 \ell_{2}}{\mathrm{r}}\right)}+\frac{1}{\mathrm{~h}_{\mathrm{A}}\left(\frac{\mathrm{R}^{2}}{\mathrm{r}^{2}}-1\right)}}
\end{aligned}
$$




$$
\begin{aligned}
\mathrm{U}_{\mathrm{U}}= & \frac{(0.5)(0.25)\left(\frac{55^{2}}{30^{2}}-1+\frac{(2)(10)}{30}\right)}{5+20+(10 / 2)+55 / 2}+\frac{1}{\frac{1}{1}+\frac{20}{100}+\frac{1}{1}+\frac{5}{0.25}+\frac{1}{1}} \\
& +\frac{\frac{1}{(2)(20)}+\frac{5+20+(55-30) / 2}{(1)(30)}+\frac{1}{(0.5)(0.25)\left[(55 / 30)^{2}-1+2(20) /(30)\right]}+\frac{1}{1\left[\left(55^{2} / 30^{2}\right)-1\right]}}{}
\end{aligned}
$$$$
=0.0066+0.0431+0.0121=0.0618 \mathrm{Btu} /(\mathrm{hr})\left(\mathrm{ft}{ }^{2}\right)\left({ }^{\circ} \mathrm{F}\right) .
$$

The maximum temperature at the bottom of the tank, Equation $(B-6)$ :

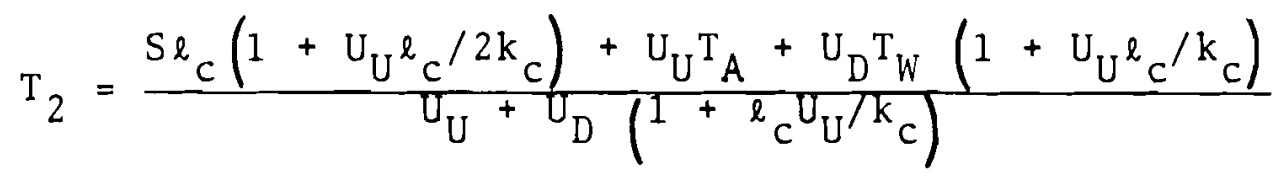

$$
\begin{aligned}
& =\{(2)(10)[(1+(0.0618)(10) /(2)(1)]+(0.0618)(30) \\
& +(0.00608)(100)(1+0.0618)(35) /(1)\} \\
& \div\{(0.0618)+0.00608[1+10(0.0618) / 1)]\} \\
& =409^{\circ} \mathrm{F} \text {. }
\end{aligned}
$$

\section{EXAMPLE 4. EXTRAPOLATION OF EXPERIMENTAL DATA}

\section{FROM ONE TANK TO ANOTHER}

- Data: $\ell_{c}=12 \mathrm{ft}, k_{c}=0.6, Q=40,000 \mathrm{Btu} / \mathrm{hr}$,

$$
\mathrm{T}_{\mathrm{A}}=\mathrm{T}_{\mathrm{W}}=70^{\circ} \mathrm{F} \quad \mathrm{r}=37.5 \mathrm{ft}
$$

- The measured temperature $\mathrm{T}_{2}$ at the bottom of the cake is $50{ }^{\circ} \mathrm{F}$ and it is estimated that $5000 \mathrm{Btu} / \mathrm{hr}$ goes to the water table. Suppose a solidification in a similar tank is planned, which will contain heat generators emitting $20,000 \mathrm{Btu} / \mathrm{hr}$ to be concentrated to an $8 \mathrm{ft}$ cake, with a cake thermal conductivity of 0.3 .

- What is the maximum temperature in the cake? 
Position of maximum cake temperature:

$$
x_{N}=12 \mathrm{ft} \times \frac{5,000}{40,000}=1.5 \mathrm{ft} .
$$

The volumetric heat generation rate:

$$
S=\frac{Q}{\pi r^{2} \ell_{c}}=\frac{40,000}{(\pi)(37.5)^{2}(12)}=0.755 \mathrm{Btu} /(\mathrm{hr})\left(\mathrm{ft}^{3}\right)
$$

The cake-to-water table heat transfer coefficient Equation $(B-4):$

$$
\mathrm{U}_{\mathrm{D}}=\frac{{ }^{S X_{N}}}{\mathrm{~T}_{2}-\mathrm{T}_{W}}=\frac{(0.755)(1.5)}{500-70}=0.00263 \mathrm{Btu} /(\mathrm{hr})\left(\mathrm{ft}{ }^{2}\right)\left({ }^{\circ} \mathrm{F}\right)
$$

The cake-to-atmosphere heat transfer coefficient Equation $(B-7)$ :

$$
\begin{aligned}
U_{U}= & \frac{S_{\ell_{C}}-U_{D}\left(T_{2}-T_{W}\right)}{\left(T_{2}-T_{W}\right)\left[1+\left(U_{D}{ }_{c} / k_{c}\right)\right]-\left(S_{l_{c}}^{2} / 2 k_{c}\right)} \\
= & {[(0.755)(12)-(0.00263)(500-70)\} } \\
& \div\{(500-70)[1+(0.00263)(12) /(0.6)] \\
& \left.-(0.755)(12)^{2} /(2)(0.6)\right\} \\
= & 0.0219 \mathrm{Btu} /(\mathrm{hr})\left(\mathrm{ft}^{2}\right)\left({ }^{\circ} \mathrm{F}\right) .
\end{aligned}
$$

It is a good approximation to assume that $U_{U}$ and $U_{D}$ do not change as the cake thickness is changed.

For the new tank

$$
\left.S=\frac{Q}{\pi r^{2} \ell_{c}}=\frac{20,000}{(\pi)(37.5)^{2}(8)}=0.566 \mathrm{Btu} /(\mathrm{hr})(\mathrm{ft})^{3}\right) .
$$

The maximum temperature at the bottom of the cake, Equation $(B-7):$ 


$$
\begin{aligned}
T_{2} & =T_{W}+\frac{S \ell_{C}\left(1+U_{U} \ell_{C} / 2 k_{C}\right)}{U_{U}+U_{D}\left(1+\ell_{C} U_{U} / k_{C}\right)} \\
& =70+\frac{(0.566)(8)[1+(0.0219)(8) /(2)(0.3)]}{(0.0219)+(0.00263)[1+(0.0219)(8) / 0.3]} \\
& =294^{\circ} \mathrm{F} .
\end{aligned}
$$

The position of the maximum cake temperature:

$$
X_{N}=(1.5)\left(\frac{8}{12}\right)=1.0 \mathrm{ft} \text {. }
$$

The maximum cake temperature, Equation (B-3):

$$
\begin{aligned}
\mathrm{T}_{\text {MAX }} & =\mathrm{T}_{2}+\frac{\mathrm{SX}_{\mathrm{N}}^{2}}{2 \mathrm{k}_{\mathrm{C}}} \\
& =294+\frac{(0.566)(1)^{2}}{(2)(0.3)}=295^{\circ} \mathrm{F} .
\end{aligned}
$$

\section{EXAMPLE 5. EFFECT OF STRATIFICATION}

- In the case of Example 4, a core drill sample of the $8 \mathrm{ft}$ cake shows that all the heat-generating fission products are concentrated in a layer located between 3 and $3.5 \mathrm{ft}$ above the bottom of the cake.

- What is the maximum temperature in the cake?

$U_{U}$ redefined as the heat transfer coefficient from the top of the heat-generating 1 ayer, Equation (B-17):

$$
\mathrm{U}_{\mathrm{U}}=\frac{1}{\frac{8-3.5}{0.3}+\frac{1}{0.0219}}=0.0165 \mathrm{Btu} /(\mathrm{hr})\left(\mathrm{ft}^{2}\right)\left({ }^{\circ} \mathrm{F}\right) \text {. }
$$

$\mathrm{U}_{\mathrm{D}}$ redefined as the heat transfer coefficient from the top of the heat-generating layer, Equation (B-18):

$$
\mathrm{U}_{\mathrm{D}}=\frac{1}{\frac{3.0}{0.3}+\frac{1}{0.00263}}=0.00257 \mathrm{Btu} /(\mathrm{hr})\left(\mathrm{ft}^{2}\right)\left({ }^{\circ} \mathrm{F}\right) \text {. }
$$



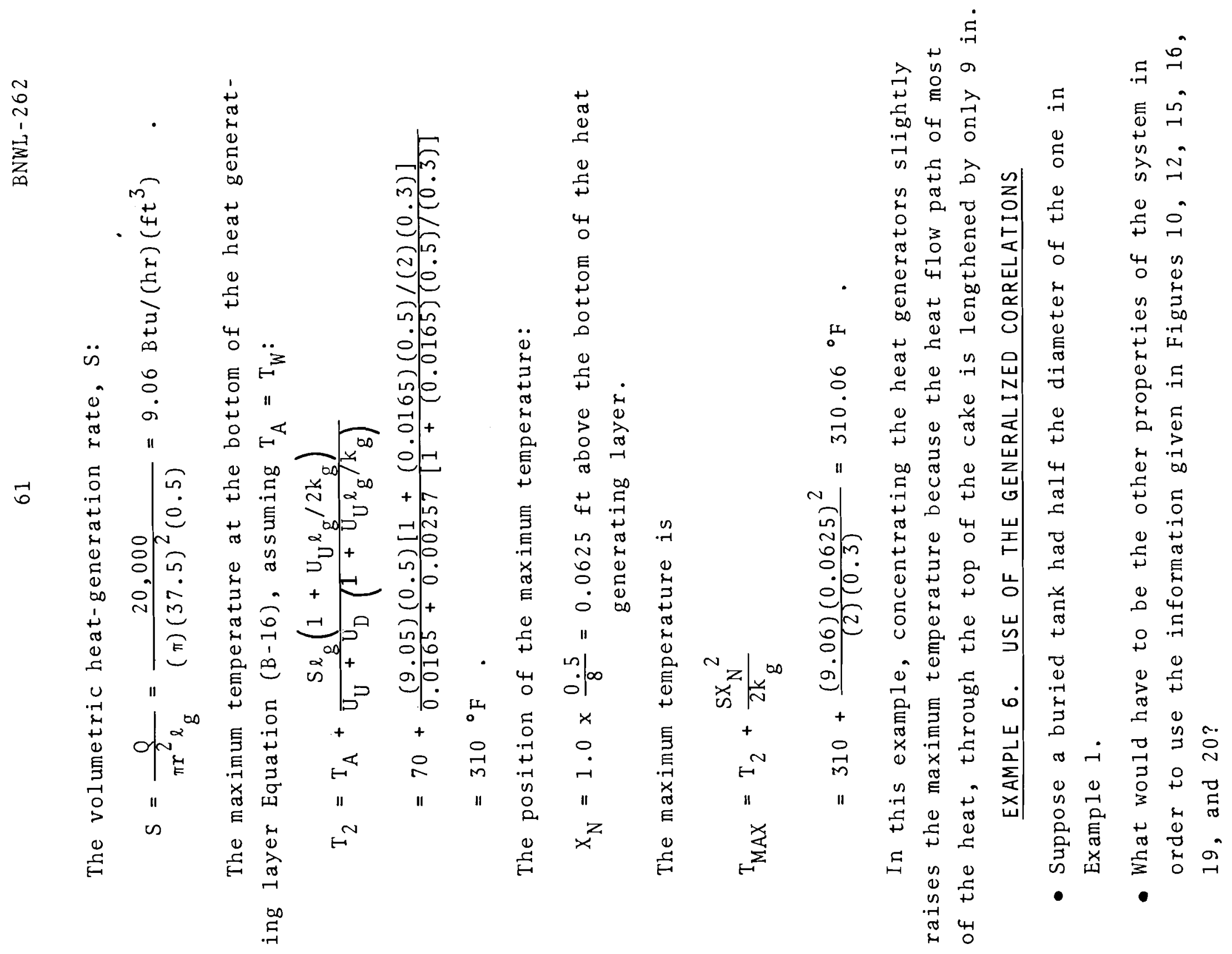
Using Equation (12), page 27, the answers are:

$$
\begin{aligned}
& \ell_{1}^{\prime}=5.5 \mathrm{ft}, \ell_{2}^{\prime}+\ell_{c}^{\prime}=18 \mathrm{ft}, \ell_{c}^{\prime}=8 \mathrm{ft}, \ell_{3}^{\prime}=78.5 \mathrm{ft}, \\
& R^{\prime}=30 \mathrm{ft}, r^{\prime}=18.75 \mathrm{ft}, T_{A}=T_{W} .
\end{aligned}
$$

- If the total heat generation rate were $3000 \mathrm{Btu} / \mathrm{hr}$ and the thermal conductivities were $\mathrm{k}_{\mathrm{C}}=1.20, \mathrm{k}_{\mathrm{S}}=0.15, \mathrm{~T}_{\mathrm{A}}=70^{\circ} \mathrm{F}$, what would the maximum temperature be at the bottom of the tank?

$$
\begin{aligned}
\mathrm{k}_{\mathrm{C}} / \mathrm{k}_{\mathrm{S}} & =1.20 / 0.15=8 \\
\mathrm{~S} & =\frac{3000}{(\pi)(18.75)^{2}(8)}=0.340 \mathrm{Btu} /(\mathrm{hr})\left(\mathrm{ft}^{3}\right)
\end{aligned}
$$

From Figure $12\left(\ell_{c}=16 \mathrm{ft}, \mathrm{k}_{c} / \mathrm{k}_{\mathrm{s}}=8\right)$

$$
\frac{\mathrm{k}_{\mathrm{s}}\left(\mathrm{T}_{2}-\mathrm{T}_{\mathrm{A}}\right)}{\mathrm{S}}=120 \mathrm{ft}^{2} \text {. }
$$

The maximum temperature

$$
\mathrm{T}_{2}=70+\frac{(120)(0.340)}{0.15}=342^{\circ} \mathrm{F} \text {. }
$$

With the tank diameter fixed only one other dimension at a time can be different from the basic case. For example, suppose $R^{\prime}$ were changed to $40 \mathrm{ft}(80 \mathrm{ft}$ center-to-center tank spacing). Then $\mathrm{R}=80 \mathrm{ft}$ and from Figure 16

$$
\frac{\mathrm{k}_{\mathrm{S}}\left(\mathrm{T}_{2}-\mathrm{T}_{\mathrm{A}}\right)}{\mathrm{S}}=173 \mathrm{ft}^{2} \text { for } 2 \mathrm{R}=160 \mathrm{ft} \text {. }
$$

Thus $\mathrm{T}_{2}=462^{\circ} \mathrm{F}$ for this case. 


\section{REFERENCES}

1 J. J. Shefcik. Operating Experience on In-Tank Solidification of Radiochemical Wastes, ISO-SA-1, presented at Symposium on the Solidification and Long-Term Storage of Highly Radioactive Wastes, Richland, Washington. February 14-18, 1966.

2. R. E. Tomizinson. The Hanford Program for Management of High Level Waste, $\overline{H W-S A}-2515$ REV, presented at the AIChE Meeting at Buffalo, New York, May 5-8, 1963.

3. D. W. McLenegan. Temperature Transients in Underground Tanks Storing Nuclear Process Residues, HW-56821. General Electric Company, Richland, Washington, July 28, 1958.

4. E. Doud and $H$. W. Stivers. Limitations for Existing Storage Tanks for Radioactive wastes from Separations Plants, HW-59919. General Electric Company, Richland, Washington, October 22, 1959.

5. M. W. Cook. The Design and Application of a Heat Transfer Analogue for Radially Symmetric Problems, HW-47088. General Electric Company, Richland, Washington, January 30, 1957.

6. M. W. Cook and J. M. Gerhart. Waste Tank Temperature Studies, HW-47087. General Electric Company, Richland, Washington, January 28, 1957. (Secret)

7. G. Jansen, Jr., W. E. Willingham, and W. V. DeMier. Buried Radioactive waste Storage Tank Temperatures and Soil Temperatures Near Leaks, BNWL-181. February 1966.

8. Research and Development Activities - Fixation of Radioactive Residues, Quarterly Progress Report, OctoberDecember 1964, edited by A. M. Platt, HW-84603, pp. 43-49, General Electric Company, Richland, Washington. January 1965 .

9. Research and Development Activities - Fixation of Radioactive Residues, Quarterly Progress Report, JanuaryMarch 1965, edited by A. M. Platt, BNWL-76, pp.31-32. April 1965 .

10. Research and Development Activities - Fixation of Radioactive Residues, Quarterly Progress Report, April-June 1965, edited by A. M. Platt, BNWL-139. July 1965.

11. G. Jansen, Jr., W. E. Willingham, and W. V. DeMier. Heat Transfer in Underground Tank Storage of Radioactive wastes, BNWL-SA-468, presented at the Symposium on the Solidification and Long-Term Storage of Highly Radioactive Wastes, Richland, washington, February 14-18, 1966. 
12. H. S. Davis. Effects of High Temperature Exposure on Concrete, RLSA-20. General Electric Company, Richland, Washington, February 16, 1965.

13. E. Z. Block. Program Index, Fortran Library. General Electric Company, Richland, Washington. May 15, 1965.

14. G. M. Dusinberre. Heat Transfer Calculations by Finite Differences, International Textbook Co., Scranton, Pa., 1961 .

15. P.J. Schneider. Conduction Heat Transfer, Addison-Wesley Publishing Co., Inc., Reading, Mass., 1955.

16. M. Jakob. Heat Transfer, John Wiley and Sons, Inc., New York, N.Y., 1950 .

17. H. S. Carslaw and J. C. Jaeger. Conduction of Heat in Solids, Oxford at the Clarendon press, 1959. 2nd ed., Chapter 14 . 


\section{DISTRIBUTION}

Number

of Copies

257 Division of Technical Information Extension

2 Idaho Nuclear Corporation

B. R. Dickey

D. E. Black

15 Isochem Inc.

S. J. Beard

D. J. Brown

J. B. Fecht

M. K. Harmon

W. M. Harty

O. F. Hill

G. R. Kiel

R. W. McCuliugh

H. C. Rathvon

H. P. Shaw

J. J. Shefcik

R. J. Sloat

O. V. Smiset

R. E. Tomlinson

L. L. Zahn

1 Union Carbide Corporation (ORNL)

R. L. Bradshaw

2 Richland Operations Office

R. K. Sharp

Technical Information Library

44 Battelle-Northwest

G. J. A1kire

J. M. Atwood

R. E. Burns

C. R. Cooley

W. V. DeMier

A. G. Gibbs

W. A. Haney

E. R. Irish

G. Jansen

B. M. Johnson
L. G. King

R. W. Ne1son

D. W. Pearce

A. M. P1 att

W. H. Swift

E. E. Voil and

M. T. Walling

W. E. Willingham (10)

Technical Information

Technical Publications 


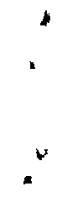

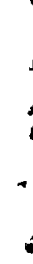

.

.

.

. 